Pablo Castillo, Juan A. Navas-Cortés, and Blanca B. Landa

Institute of Sustainable Agriculture (IAS), CSIC, Córdoba, Spain

\author{
Rafael M. Jiménez-Díaz \\ IAS-CSIC and University of Córdoba (UCO), Córdoba, Spain \\ Nicola Vovlas \\ Istituto per la Protezione delle Piante, C.N.R., Bari, Italy
}

\title{
Plant-Parasitic Nematodes Attacking Chickpea and Their In Planta Interactions with Rhizobia and Phytopathogenic Fungi
}

\begin{abstract}
Chickpea (Cicer arietinum) is a coolseason food legume second in importance as a pulse crop in the world after beans (Phaseolus vulgaris). It is an important protein source in many regions of the semi-arid tropics (30). Chickpea is grown in 47 countries and is a significant component of subsistence cropping systems for farmers in the Indian Subcontinent, West Asia, the Mediterranean Basin, and certain areas of East and North Africa. More than $90 \%$ of the chickpea crops are grown in eight countries, including India, Pakistan, Iran, Turkey, Ethiopia, Mexico, Australia, and Canada, in decreasing order.

Many species of plant-parasitic nematodes have been reported in the roots and rhizosphere of chickpea in the major growing regions in the world (Table 1). However, only certain nematode species are considered constraints to chickpea production, causing an estimated $14 \%$ in annual yield losses $(61,68)$. The symptoms and signs of nematode parasitism on chickpea differ depending upon the nematode's feeding habit. Moreover, nematode attacks can make plants more sensitive to other biotic and abiotic stresses, and overall result in stunting and poor yield (70). Symptoms caused by nematode attack are nonspecific and nondescript, and they are largely a consequence of disruption of normal processes of plant growth, and absorption and translocation of water and nutrients. Consequently, damage by nematodes to chickpea often goes unnoticed and is attributed to other causes, such as lack
\end{abstract}

Corresponding author: P. Castillo, Research Scientist, Institute of Sustainable Agriculture (IAS), Spanish Council for Scientific Research (CSIC), P.O. Box 4084, 14080 Córdoba, Spain; E-mail: pcastillo@ias.csic.es

doi:10.1094/PDIS-92-6-0840

(c) 2008 The American Phytopathological Society of fertility or deficient soil moisture. For example, even $50 \%$ reductions in chickpea yield caused by the chickpea cyst nematode, Heterodera ciceri, cannot be predicted by inspection of the upper part of the plant (35). For these reasons, plantparasitic nematodes are often referred to as the "unseen enemies" of crops.

The most important nematode pathogens of chickpea include root-knot nematodes (Meloidogyne spp.), root-lesion nematodes (Pratylenchus spp.), cyst-forming nematodes (Heterodera spp.), and the reniform nematode (Rotylenchulus reniformis). In this paper, we will focus on the geographical distribution and pathogenicity of these nematodes, along with the symptoms, epidemiology, and management of the diseases they cause on chickpea. In addition, we will describe some of the most common and efficient diagnostic methods that are available for nematodes. Finally, we will address the complex interactions that occur between some nematodes and other microorganisms that coinfect chickpea, including rhizobia and the fungal pathogen Fusarium oxysporum f. sp. ciceris, which causes Fusarium wilt.

\section{Root-Knot Nematodes}

Sedentary endoparasitic root-knot nematodes of the genus Meloidogyne are among nature's most successful plant parasites. Meloidogyne species infect thousands of different hosts, including herbaceous and woody monocotyledonous and dicotyledonous plants, and cause serious losses to numerous agricultural crops worldwide $(28,57,61)$. The root-knot nematode species known to damage chickpea are $M$. arenaria, $M$. incognita, and $M$. javanica, warm climate species that attack chickpea in the Indian Subcontinent, and M. artiellia, a species well adapted to cool and wet conditions, that is widely distributed in the Mediterranean Basin (3,9,70).
Root galling is the typical symptom of parasitism by Meloidogyne spp. in susceptible crops. However, compared with large galls induced by $M$. arenaria, $M$. incognita, and $M$. javanica on chickpea, $M$. artiellia produces small galls or no galls (85). The most evident sign in roots infected by this latter species are the egg masses produced by the nematode, which may contain 200 to 600 eggs (Fig. 1) (39). The limited hyperplasia in the vascular cylinder and the cortical cells that surround the feeding site of $M$. artiellia seems to determine the small gall size in this species (85). Also, the frequently observed protrusion of bodies of adult $M$. artiellia females from infected roots, resembling the parasitic habit of adult cyst-nematode females, seems to be congruent with the lack of root galling (Fig. 1).

Parasitism by root-knot nematodes in chickpea involves the establishment of permanent feeding sites called giant cells in the root cortex, endodermis, pericycle, and vascular parenchyma (85). Feeding sites are sinks for plant photosynthate. In addition, deformation and blockage of vascular tissues at feeding sites limit translocation of water and nutrients, and further suppress plant growth and reduce seed yield $(57,85)$. In chickpea, the number of giant cells in the feeding site (averaging four to six) and the area of individual giant cells are not influenced by root-knot nematode species or isolates within species (85). However, the number of nuclei per giant cell is significantly lower for $M$. artiellia than for $M$. arenaria, $M$. incognita, or $M$. javanica (Fig. 2). Similarly, maximum diameters of nuclei and nucleoli are significantly greater in giant cells induced by $M$. artiellia isolates compared with those induced by $M$. arenaria, $M$. incognita, or M. javanica (85) (Fig. 2).

Uneven patches of chickpea plant growth are commonly associated with soils 
infested with root-knot nematodes. Heavily infected plants show stunted growth, less branching, and leaves with pale green to yellow color (Fig. 3A). The extent of yield loss caused by root-knot nematodes is determined by a number of factors, including the nematode species, the population density, pattern of nematode distribution in soil, the soil cropping history, chickpea cultivar, climate, and soil type. Although a variety of mathematical functions have been proposed to describe the relationships between the initial nematode population density in soil and crop damage, the most widely accepted one is the Seinhorst model $\left[y=m+(1-m) z^{P-T}\right.$ when $P \geq T$, and $y=1$ when $P<T]$ (63). In this model, $y=$ relative value of the plant growth parameter being measured; $m=$ the minimum value of $y$ ( $y$ at a very large ini- tial nematode population density); $P=$ the initial nematode population density; $T=$ the tolerance limit (initial population at which plant growth is not impaired; and $z$ $=\mathrm{a}$ constant $<1$ reflecting nematode damage, with $z^{-T}=1.05$ (Fig. 4). Threshold levels for $M$. incognita and $M$. javanica on chickpea grown under greenhouse conditions were established at 0.2 to 2.0 secondstage juveniles (J2) per gram of soil $(52,58,64)$; however, tolerance to $M$. javanica was identified in some chickpea cultivars (65). Comparatively, the tolerance limits of chickpeas to infection by $M$. artiellia under field conditions in microplot experiments were much lower, i.e., 0.14 and $<0.02$ eggs and $\mathrm{J} 2$ per $\mathrm{cm}^{3}$ of soil for winter- and spring-sown crops (Fig. 4), respectively (20). Chickpea yield losses of up to $60 \%$ were caused by severe $M$. in- cognita infections in India (3); whereas in southern Italy, initial $M$. artiellia populations of 2 eggs and $\mathrm{J} 2$ per $\mathrm{cm}^{3}$ of soil caused a yield reduction of $50 \%$ in winter sowings, and about $80 \%$ in spring sowings (20).

Meloidogyne spp. attacking chickpea have a wide host range including many weeds, which constitute natural, alternative hosts for the nematodes and enable their survival and population increase (Fig. 3B) $(13,69)$. Moisture, texture, and temperature are major soil physical factors affecting distribution and reproduction of those nematodes. $M$. artiellia completes one generation per growing season (21), mostly because of a combination of low, insufficient rainfall and high temperature that prevail in spring in the Mediterranean Basin. However, Meloidogyne spp. infect-
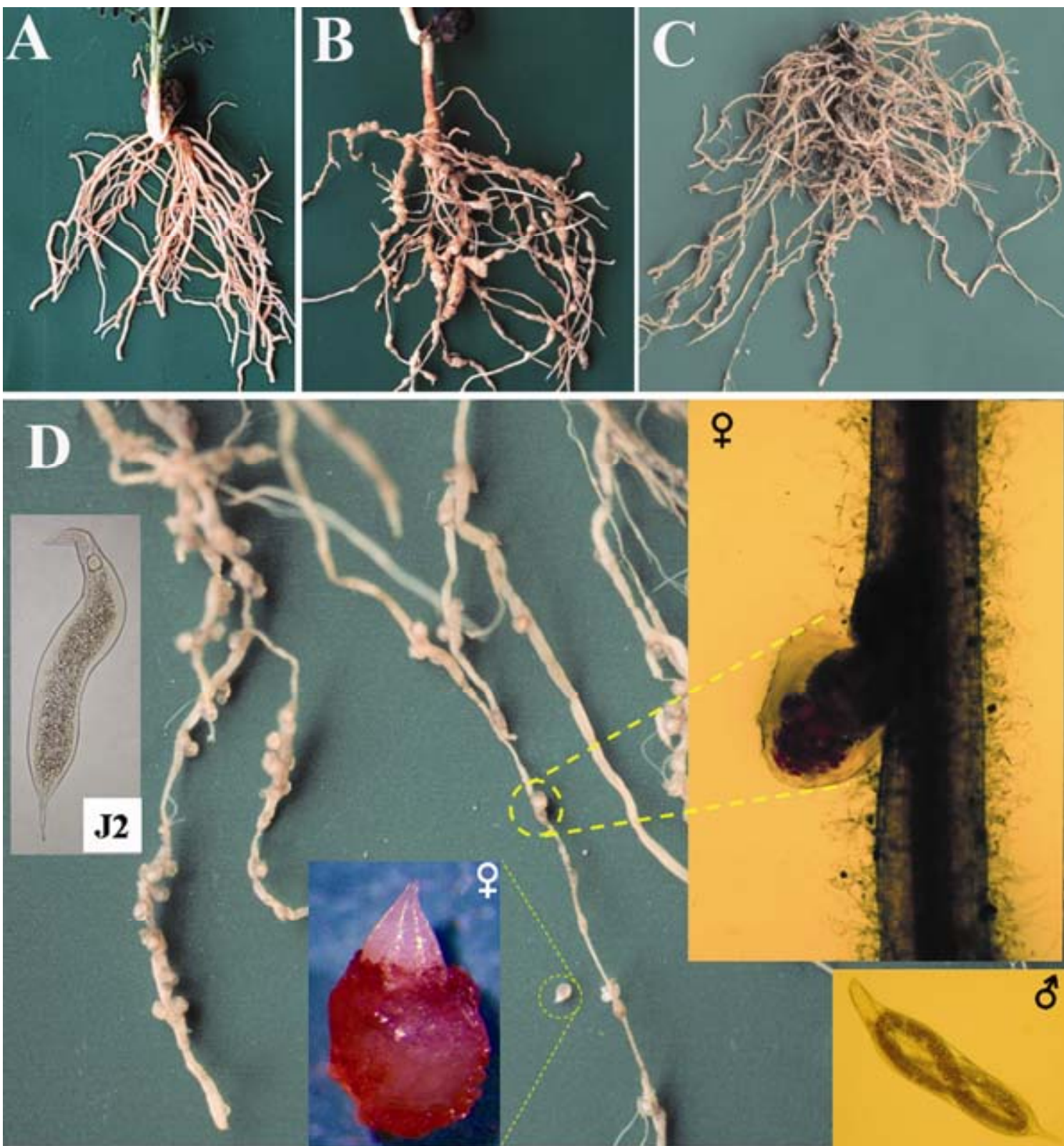

우

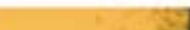


ing chickpea in the Indian Subcontinent can complete several generations within a growing season, leading to a very high postharvest nematode population density in soils (3). In any case, all these Meloidogyne species can persist in infested soils for 2 to 3 years protected within the infected root tissues, in the egg masses, or as $\mathrm{J} 2$ in anhydrobiosis $(21,70)$.

Cultural practices play a vital role in the management of nematode-induced diseases in subsistence farming because crops of low value rarely receive any major input of fertilizer or pesticides. Although soil treatments with nematicides or solarization have been effective in the management of root-knot nematodes in chickpea, their use is prohibitively expensive (70). Fallowing is practiced commonly in Turkey and Syria to reduce nematode soil population densities by 35 to $50 \%$ per year (70). In the Indian Subcontinent, crop rotation is difficult because of the wide host range of warm-climate Meloidogyne species. Nevertheless, crops such as groundnut and winter cereals are not suitable hosts for $M$. arenaria, $M$. incognita, and $M$. javanica (70) and could therefore be included in rotation with chickpea. Conversely, $M$. artiellia in chickpea could be effectively managed in the Mediterranean Basin by rotation with nonhosts such as cotton, sugar beet, potato, maize, or lentil. Unfortunately, the most common crop rotation for legumes is with winter cereals, which is not useful for management of $M$. artiellia because the nematode is well adapted to winter cereals $(25,39)$. Finally, although chickpea germplasm with resistance to $M$. incognita and $M$. javanica has been identified in India (65), poor agronomic characteristics have limited its use by farmers. Resistance to $M$. artiellia is not available, although resistance has been found in some accessions of wild Cicer species, including C. bijugum, C. chorassanicum, C. judaicum, C. pinnatifidum, and C. reticulatum (26).

\section{Root-Lesion Nematodes}

Root-lesion nematodes are major constraints to chickpea production and rank second after the root-knot nematodes in terms of their global economic impact on crops $(15,61)$. This is due to their wide host ranges as well as to their occurrence in almost any climate. Root-lesion nematodes are migratory endoparasites that damage chickpea roots by feeding in the cortical parenchyma and causing extensive necrosis of epidermal, cortical, and endodermal cells $(15,16)$. Both penetration of the root and migration within root tissues are facilitated by a combination of stylet thrusting and enzymatic softening of the host cell walls (15). Under field conditions, root-lesion nematode damage to chickpea occurs in patches, with affected plants showing stunting, leaf chlorosis, root necrosis, and reduction of root growth and shoot weight as a result of destruction of cortical parenchyma (Fig. 5).

Although species from three genera of root-lesion nematodes have been reported parasitizing chickpea, i.e., Pratylenchoides, Pratylenchus, and Zygotylenchus (Table 1), those of Pratylenchus are found most commonly in chickpea growing areas. The two major species most frequently diagnosed as causing damage to chickpea worldwide are the cereal and legume rootlesion nematode, Pratylenchus thornei (Fig. 6), and P. penetrans $(9,15,22,23,70)$. In general, Pratylenchus species complete several generations per growing season, with each generation requiring about 1 month. Although large numbers of rootlesion nematodes may occur in infected roots early in the growing season, nematode populations in soil are rather low, especially in the absence of a host crop
(15). Some weed species are good hosts for Pratylenchus species, thus suggesting the need for implementing efficient weed management practices to reduce the nematode population in the soil and subsequent damage to crops $(43,83)$.

$P$. thornei reproduces by mitotic parthenogenesis (31). Females of $P$. thornei lay eggs in the cortex, and the nematode completes its life cycle in about 4 weeks under suitable environmental conditions. $P$. thornei has a wide host range, including highly susceptible crops such as grain legumes (e.g., chickpea, faba bean, lentil, pea, and vetch) and small grain cereals; and moderately susceptible crops such as cauliflower, lettuce, and potato. Spinach and sugar beet are resistant to P. thornei (36). Under field conditions in Syria, the tolerance limit of chickpea to $P$. thornei was as low as 0.031 nematodes per $\mathrm{cm}^{3}$ of

Table 1. Plant-parasitic nematodes associated with chickpea ${ }^{\mathrm{a}}$

\begin{tabular}{|c|c|c|}
\hline Nematode group and species & $\begin{array}{l}\text { Threshold level } \\
\text { (nematodes per } \\
\text { cm }^{3} \text { or g soil) }\end{array}$ & Country/region \\
\hline \multicolumn{3}{|l|}{ Root-knot nematodes } \\
\hline \multicolumn{3}{|l|}{ Meloidogyne spp. } \\
\hline M. arenaria & - & Ghana, India, North Africa, Syria \\
\hline M. artiellia & $0.02-0.14$ & North Africa, Syria \\
\hline M. incognita & $1.0-2.0$ & Brazil, Egypt, India, Pakistan \\
\hline M. javanica & $0.1-4.28$ & Brazil, Egypt, Ethiopia, India, Pakistan \\
\hline \multicolumn{3}{|l|}{ Root-lesion nematodes } \\
\hline \multicolumn{3}{|l|}{ Pratylenchoides spp. } \\
\hline P. alkani & - & Syria \\
\hline P. erzurumensis & - & Turkey \\
\hline P. leiocauda & - & Turkey \\
\hline P. ritteri & - & Algeria, Tunisia \\
\hline \multicolumn{3}{|l|}{ Pratylenchus spp. } \\
\hline P. alleni & - & Turkey \\
\hline P. brachyurus & - & Brazil, Turkey \\
\hline P. coffeae & - & India \\
\hline P. mediterraneus & - & North Africa, Syria, Turkey \\
\hline P. mulchandi & - & India \\
\hline P. neglectus & - & Australia, North Africa, Spain, USA \\
\hline P. penetrans & - & North Africa, Spain, Turkey \\
\hline P. thornei & 0.031 & $\begin{array}{l}\text { Australia, India, Mexico, North } \\
\text { Africa, Spain }\end{array}$ \\
\hline P. zeae & - & Turkey \\
\hline Zygotylenchus guevarai & - & North Africa, Spain, Turkey \\
\hline \multicolumn{3}{|l|}{ Cyst nematodes } \\
\hline \multicolumn{3}{|l|}{ Heterodera spp. } \\
\hline H. cajani & - & India \\
\hline H. ciceri & $0.4-1.4$ & Syria, Turkey \\
\hline H. goettingiana & - & North Africa \\
\hline H. swarupi & - & India \\
\hline \multicolumn{3}{|l|}{ Reniform nematodes } \\
\hline \multicolumn{3}{|l|}{ Rotylenchulus spp. } \\
\hline R. reniformis & $0.5-1.0$ & India \\
\hline R. macrosoma & - & Syria \\
\hline \multicolumn{3}{|l|}{ Stem and bulb nematodes } \\
\hline Ditylenchus dipsaci & - & Australia \\
\hline \multicolumn{3}{|l|}{ Stunt and spiral nematodes } \\
\hline Amplimerlinius magnistylus & - & Spain \\
\hline Aorolaimus perscitus & - & Spain \\
\hline \multicolumn{3}{|l|}{ Basirolaimus spp. } \\
\hline B. columbus & - & India \\
\hline B. dimorphicus & - & India \\
\hline B. indicus & - & India, Pakistan \\
\hline \multirow[t]{2}{*}{ B. seinhorsti } & - & India \\
\hline & & (continued on next page) \\
\hline
\end{tabular}


soil (Fig. 4), with chickpea yield being reduced to about $40 \%$ with a nematode population at planting of 2 nematodes per $\mathrm{cm}^{3}$ of soil (24). Experiments in growth chambers demonstrated that root weight was significantly reduced by $P$. thornei infections, which reached high populations in all tested chickpea genotypes except for cv. JG 62, which showed tolerance to $P$. thornei (16). Results also demonstrated that nematode reproduction was significantly influenced by chickpea genotype, with cvs. JG 62 and UC 27 being the best and poorest hosts, respectively, independent of the geographical origin of the nematode isolate (16).

P. thornei appears to be adapted to suppress root growth more severely under warm, dry soils than in cool, moist soils, typical of areas with in-season rainfall or with irrigation (10). Under controlled conditions, chickpea root growth was signifi- cantly reduced by $P$. thornei in plants grown under water stress and fluctuating temperatures in the greenhouse, but root growth was not affected if soil was maintained at water-holding capacity in a shadehouse with moderate air temperatures (10). In this context, Castillo et al. $(9,14)$ determined that the reproductive rate for $P$. thornei, as well as hatching and penetration of chickpea roots, increase as soil temperature rises from 15 to $20^{\circ} \mathrm{C}$.

In the absence of a host crop, Pratylenchus species survive by means of several strategies, but particularly on roots of weeds or in the soil in a quiescent state (anhydrobiosis). The ability of Pratylenchus species to undergo anhydrobiosis is the main reason that these nematodes are difficult to eradicate from infested fields (15). Anhydrobiosis of $P$. thornei was observed in Israel and southern Spain, where nematodes survived the dry fallow season

Table 1. (continued from previous page)

\begin{tabular}{|c|c|c|}
\hline Nematode group and species & $\begin{array}{l}\text { Threshold level } \\
\text { (nematodes per } \\
\text { cm }^{3} \text { or g soil) }\end{array}$ & Country/region \\
\hline \multicolumn{3}{|c|}{ Stunt and spiral nematodes (continued) } \\
\hline \multicolumn{3}{|l|}{ Bitylenchus spp. } \\
\hline B. brevilineatus & - & India \\
\hline B. dubius & _- & The Netherlands \\
\hline B. huesingi & - & Spain \\
\hline B. vulgaris & _ & India \\
\hline \multicolumn{3}{|l|}{ Helicotylenchus spp. } \\
\hline H. abunaamai & - & India \\
\hline H. digonicus & _- & Pakistan \\
\hline H. dihystera & - & India \\
\hline H. indicus & - & India \\
\hline H. retusus & - & India \\
\hline H. sharafati & _ & India \\
\hline H. tunisiensis & - & Spain \\
\hline Merlinius brevidens & - & India, Spain \\
\hline M. microdorus & - & Spain \\
\hline Paratrophurus loofi & - & Spain \\
\hline Scutellonema brachyurum & - & India \\
\hline Trophurus imperialis & - & Spain \\
\hline \multicolumn{3}{|l|}{ Tylenchorhynchus spp. } \\
\hline T. annulatus & - & India \\
\hline T. brassicae & - & India \\
\hline T. clarus & - & Spain \\
\hline T. elegans & - & India \\
\hline T. mashhoodi & _- & India \\
\hline T. nudus & - & India \\
\hline \multicolumn{3}{|l|}{ Ring and pin nematodes } \\
\hline \multicolumn{3}{|l|}{ Hemicriconemoides spp. } \\
\hline H. cocophilus & - & India \\
\hline H. mangiferae & _- & India \\
\hline \multicolumn{3}{|l|}{ Mesocriconema spp. } \\
\hline M. curvatum & - & Spain \\
\hline M. ornata & - & India \\
\hline M. spaherocephalum & _ & Spain \\
\hline \multicolumn{3}{|l|}{ Paratylenchus spp. } \\
\hline P. microdorus & - & Spain \\
\hline P. sheri & - & Spain \\
\hline \multicolumn{3}{|c|}{ Dagger, needle and stubby-root nematodes } \\
\hline \multicolumn{3}{|l|}{ Xiphinema spp. } \\
\hline X. basiri & - & India \\
\hline$X$. index & _ & Turkey \\
\hline$X$. italiae & - & Turkey \\
\hline X. pachtaicum & - & India, Turkey \\
\hline Longidorus elongatus & - & India \\
\hline Trichodorus mirzai & - & India \\
\hline
\end{tabular}

in soil or within root debris in an anhydrobiotic state until reactivated by fall rains $(33,76)$.

\section{Cyst-Forming Nematodes}

Cyst-forming nematodes, mainly Heterodera and Globodera spp., are more prone than other plant-parasitic nematodes to dispersion over time and space because eggs within cysts can tolerate long periods of desiccation and persist in soil for several years in the absence of a host plant. Dispersion of these nematodes is favored by agricultural operations and is rapid and widespread compared with that of other nematode species (57). Although three species of Heterodera have been reported to infect chickpea (Table 1), the chickpea cyst nematode, $H$. ciceri, is considered the most important, particularly in Syria and Turkey, where it causes considerable yield loss $(23,35)$. Heterodera cajani and $H$. swarupi were reported infecting chickpea in several localities of India $(3,4,67)$, and H. goettingiana in North Africa (22); however, significant damage to chickpea was not observed.

Soil infestations by cyst-forming nematodes are first limited to small circular areas that may further extend to include the entire field. Symptoms on infected chickpeas are more apparent at the flowering stage. Infected plants are stunted, with pale green leaves at an early stage of growth which later turn chlorotic (Fig. 7A). A reduction in the number of flowers and pods is observed in infected plants, which contain small or no seeds if heavily infected (35). Infected roots are poorly developed, lacking nitrogen-fixation nodules and showing cysts of adult nematode females as the sole diagnostic signs $(35,37)$.

Second-stage juveniles (J2) emerge from eggs inside cysts, migrate through soil, penetrate chickpea roots, and migrate intracellularly through the cortex until they settle permanently and establish their feeding sites (syncytia), where they become sedentary and swollen and remain to fulfill their life cycle (Fig. 7B and C). A syncytium expands into the root stele by subsequent fusions of several pericycle and stellar cells (Fig. 7D to F). All syncytia cells are hypertrophic with dense cytoplasm and large nuclei. Swollen females rupture root tissues with the posterior end of their bodies, which then protrude from the root surface (Fig. 7D and E). H. ciceri eggs do not undergo dormancy as described for other cyst nematodes, but egg hatching is favored by diffusates from roots of host crops (such as chickpea and pea), suitable soil moisture, and temperature of at least $10^{\circ} \mathrm{C}(34,37,42)$. At $20^{\circ} \mathrm{C}$, development of the nematode from penetration of roots by $\mathrm{J} 2$ to appearance of cysts is completed within 36 days; however, penetration of roots by $H$. ciceri is suppressed at $30^{\circ} \mathrm{C}(42)$. Insufficient soil 


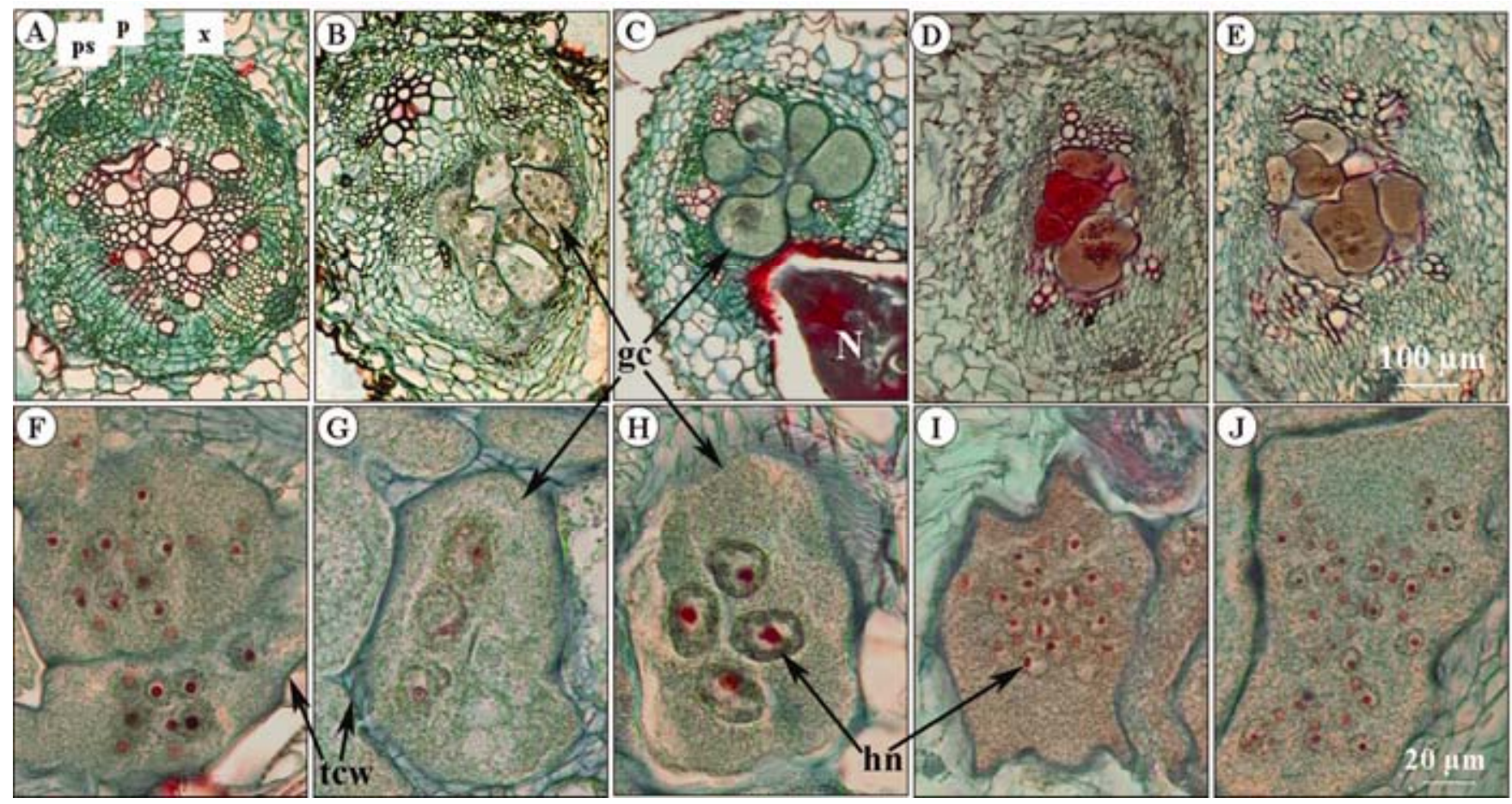

Fig. 2. Transverse sections of chickpea cultivar UC 27 stained with safranin and fast green: $A$, noninfected root; $B$, F, roots infected with Meloidogyne arenaria; C, G, H, M. artiellia; D, I, M. incognita; E, J, M. javanica, showing B-E, the anatomical changes (hypertrophy and hyperplasia) induced by nematode feeding; and F-J, details of induced giant cells. Abbreviations: gc = giant cells; hn = hypertrophied nuclei; $N=$ nematode female; $p=$ phloem; $p s=$ protoxylem elements; $t c w=$ thickened cell walls; $x=x y l e m$.



Fig. 3. A, Meloidogyne artiellia-infected chickpea plants showing stunted growth and leaves with pale green to yellow color. B, Black nightshade (Solanum nigrum) root system severely infected with Meloidogyne incognita.

moisture during the chickpea growing season, such as that occurring in Syria and Turkey, suppresses nematode infection and therefore allows the nematode to complete only one generation per cropping season (42).

Chickpea is highly susceptible to damage by $H$. ciceri. The tolerance limit of the crop ranges from 0.4 to 1.4 eggs and $\mathrm{J} 2$ per $\mathrm{cm}^{3}$ of soil (Fig. 4). Nematode population densities of 8 and 16 eggs $+\mathrm{J} 2$ per $\mathrm{cm}^{3}$ of soil can cause yield losses of 20 and $50 \%$, respectively. A complete crop failure can occur in fields infested with as few as 60 eggs $+\mathrm{J} 2$ per $\mathrm{cm}^{3}$ of soil (35). H. ciceri has a rather narrow host range among food legumes, including chickpea, lentil, and pea, but it can reproduce, although poorly, on alfalfa, bean, lupine, and Vicia spp. As a result, this nematode can be effectively controlled by crop rotations. In Syria, yield of chickpea increased by factors of 2.1, 4.5, and 7.9 in fields where suitable host crops were not sown for 1,2 , or 3 years, respectively, compared with yield produced under continuous chickpea (62). Fallowing is a common practice in Turkey and Syria, and it reduces the soil population densities of the nematode by 35 to $50 \%$ per year (35).

Potential sources of resistance to $\mathrm{H}$. $\mathrm{ci}$ ceri in genotypes of Cicer spp. that could be transferred to commercial chickpea cultivars were investigated. Unfortunately, none of 10,000 lines of $C$. arietinum screened so far $(26,77)$ were found to be resistant to $H$. ciceri; however, resistance was identified in some accessions of $C$. bijugum, C. pinnatifidum, and C. reticulatum (49,71). Among these wild Cicer species, only $C$. reticulatum is readily crossed with $C$. arietinum, the only cultivated spe- cies in the genus (49). The resistant reaction of $C$. bijugum to the cyst nematode is evidenced by the absence of syncytia and the death of several root cells surrounding the lip region of infecting J2 (Fig. 8).

\section{Reniform and Other Nematodes}

Reniform nematodes (Rotylenchulus spp.) are semi-endoparasites of roots and occur commonly in tropical and subtropical regions. The term "reniform" refers to the kidney-shape body form of the sedentary mature female protruding from infected roots (Fig. 9). Rotylenchulus reniformis is the most economically important species of reniform nematodes, and is also an important pathogen of chickpea in Egypt, Ghana, and India (Table 1) $(3,27,56,59)$. Rotylenchulus macrosoma has been reported in chickpea fields in Syria, but it has never been documented infecting chickpea roots (70). Infections of chickpea by $R$. reniformis have been associated with chickpea decline in India and Egypt. In India, high soil infestations with $R$. reniformis occur in irrigated chickpea fields, whereas population densities of this nematode are lower in rain fed areas (3). Infected plants are distributed in patches and show pale green leaves, stunted growth, and early senescence. The damage threshold for $R$. reniformis in greenhousegrown chickpeas was estimated at 0.5 to 1.0 nematodes per $g$ of soil $(18,48)$, with up to $80 \%$ yield reduction occurring at 10 nematodes per $\mathrm{g}$ of soil (48).

The life cycle of $R$. reniformis on chickpea has not been assessed, but studies in 


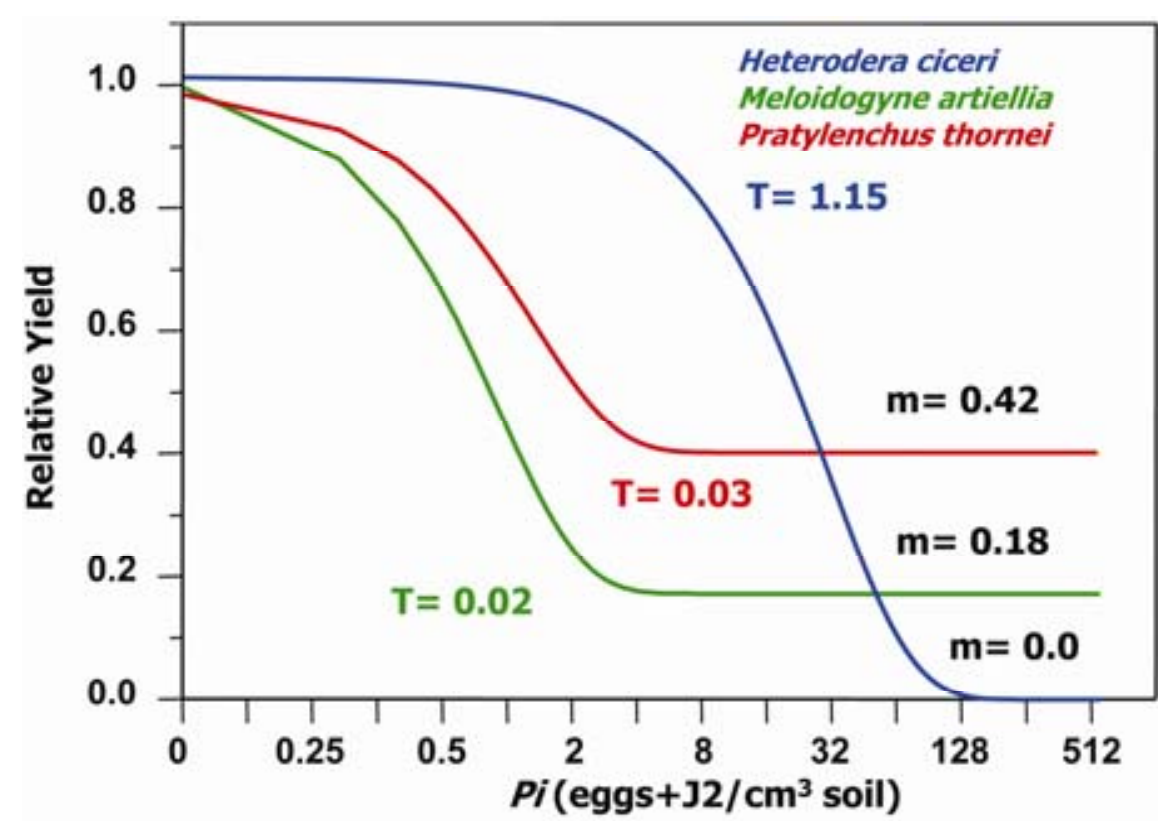

Fig. 4. Relationships between relative yield and initial population densities $(P I)$ of different species of plant-parasitic nematodes attacking chickpea. Abbreviations: $m=$ minimum value of relative yield (relative yield at a very large initial nematode population density); $T=$ tolerance limit. other susceptible hosts indicate that it takes about 25 to 30 days, depending upon soil temperature. The thermal limits for reproduction of this nematode are between 15 and $36^{\circ} \mathrm{C}$, with an optimum of $30^{\circ} \mathrm{C}$. The $\mathrm{J} 2$ and subsequent juvenile stages are not plant-parasitic. The molt of $\mathrm{J} 4$ juveniles gives rise to approximately equal numbers of vermiform parasitic females and nonparasitic males. Vermiform females penetrate the epidermis and cortical parenchyma of roots and usually stop to establish a permanent feeding site on a single endodermal cell (Fig. 9A). The anterior part of the nematode body remains embedded within the root, whereas the posterior end protrudes from the root surface and swells during maturation of the reproductive system to assume a kidneylike shape (Fig. 9A). In the stele, infective females induce the formation of a feeding site called a syncytium (Fig. 9B). This syncytium originates from an endodermal cell and enlarges subsequently by incorporating cells from the pericycle, vascular parenchyma, and sometimes phloem, by means of partial dissolution of common

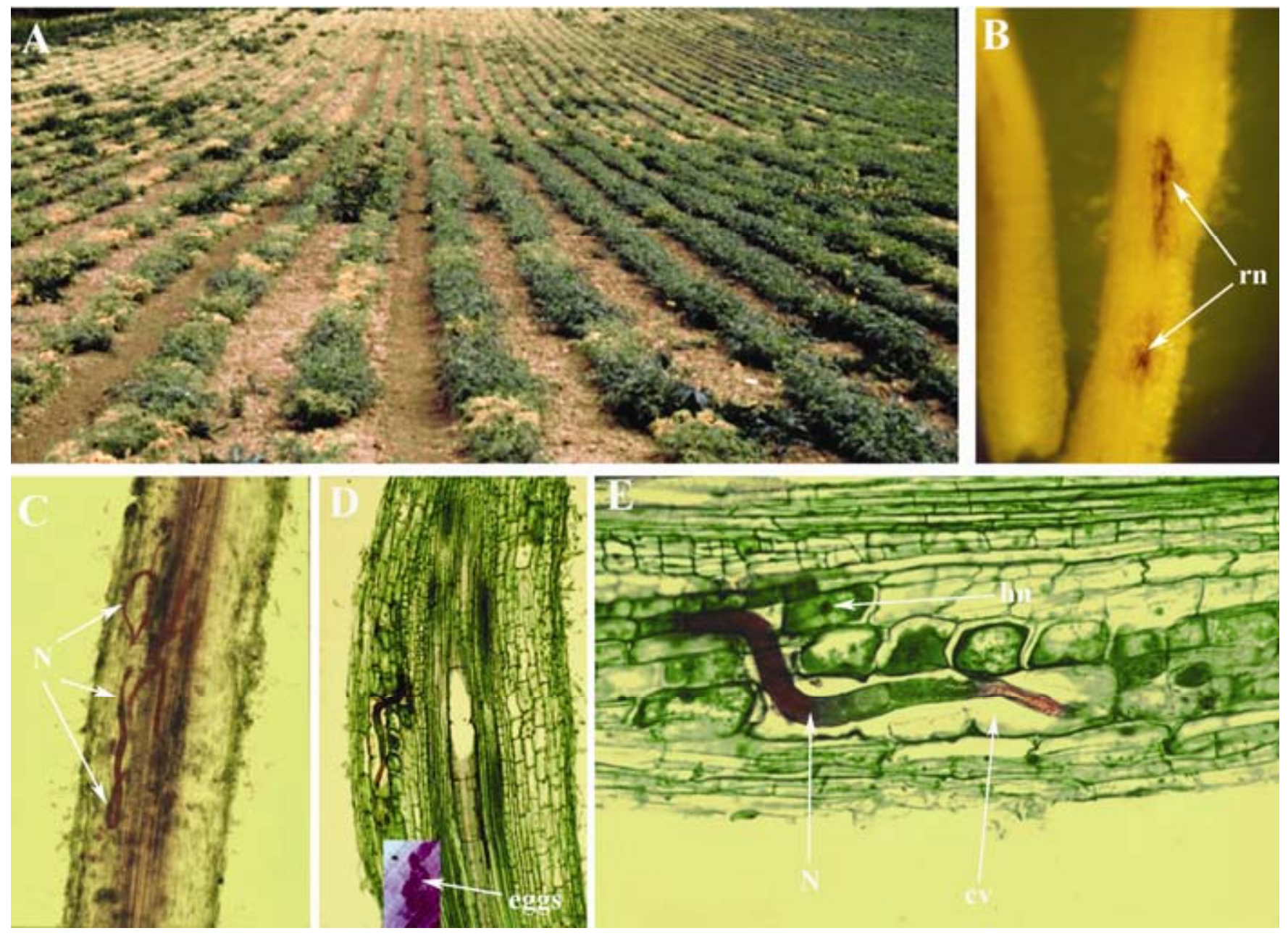

Fig. 5. A, Stunted and chlorotic chickpea plants, and B, root necrosis (rn) on roots caused by infections with Pratylenchus thornei on chickpea; C-E, Histopathological changes induced by the feeding and migration of the nematode (N) showing cavities (cv), hypertrophied nuclei (hn), and granular cytoplasm of cells adjacent to nematode pathway, and eggs deposited inside the root. 


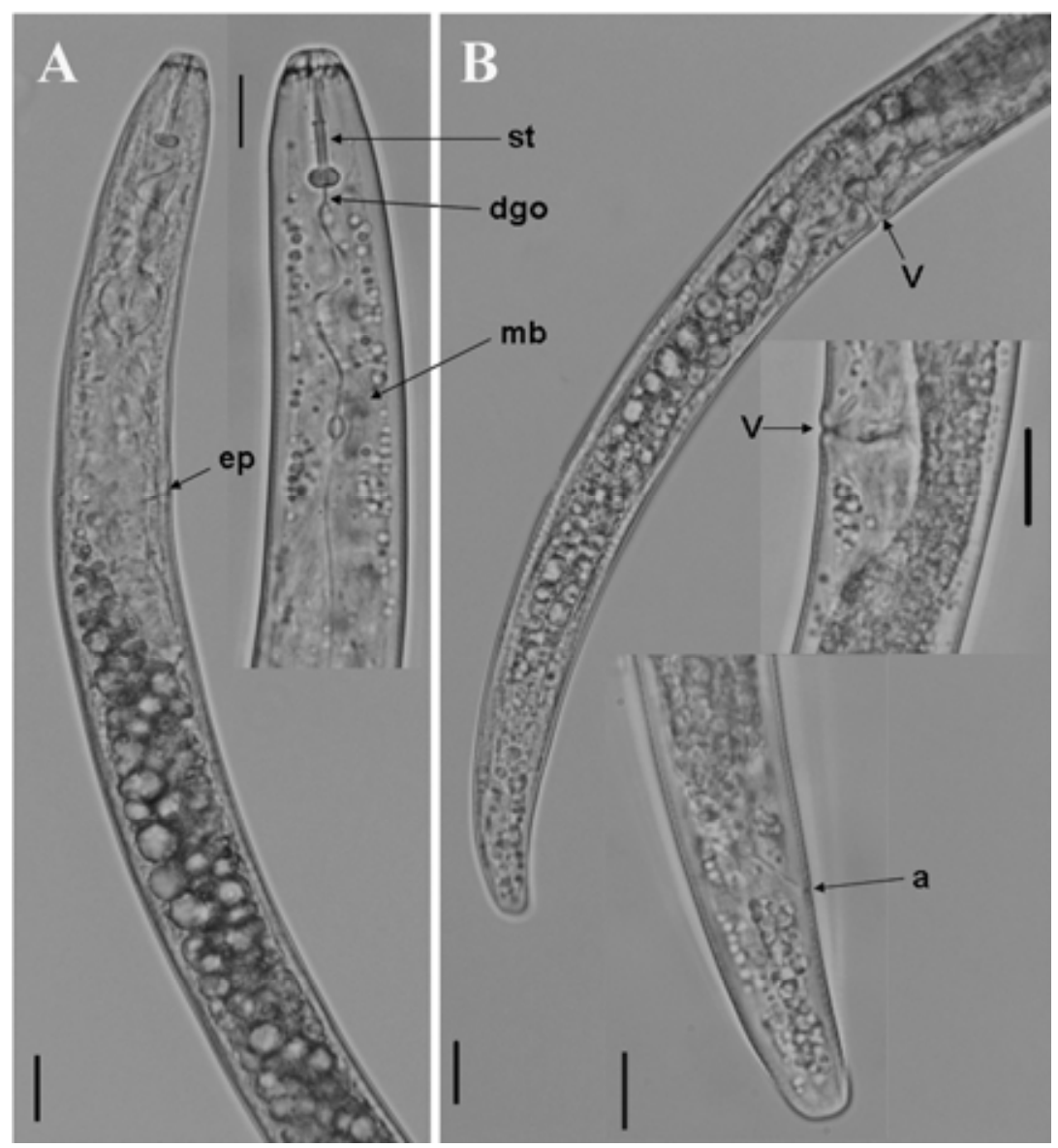

Fig. 6. Micrographs of the cereal and legume root-lesion nematode Pratylenchus thornei. A, Female anterior region showing stylet (st), dorsal pharyngeal gland orifice (dgo), median pharyngeal bulb (mb), and excretory pore (ep). B, Female posterior region showing vulva (v), tail and anus (a). Scale bars $=10 \mu \mathrm{m}$.



Fig. 7. A, Field symptoms caused by infections of chickpea with Heterodera ciceri. $\mathrm{B}$, Brown mature cysts of $\mathrm{H}$. ciceri; $\mathrm{C}$, a detail of the vulval cone under scanning electron microscopy showing fenestra. D-F, Histopathological changes induced by $H$. ciceri showing the nematode $(\mathrm{N})$, the permanent feeding site inducing syncytium (sy) with hypertrophic cells with dense cytoplasm and hypertrophied nuclei (hn); and stained with safranin and fast-green. cell walls. Syncytial cells have densely staining granular cytoplasm and enlarged nuclei, and are slightly hypertrophied (Fig. 9B). Mature females deposit between 60 and 200 eggs into a gelatinous matrix which flows out from the vulva (72).

$R$. reniformis has a wide host range, including legumes (common bean, black gram, chickpea, pigeonpea, and soybean), cereals (maize, rice, sorghum, and wheat), vegetables (cucumber, eggplant, potato, and tomato), fruits (banana, citrus, grapevine, and tropical fruits), and oilseed crops (castor, groundnut, and sunflower). Consequently, management of $R$. reniformis by crop rotation is very difficult to practice, and alternative nonhost crops must be tested before they can be recommended. Other practices such as altering planting dates have had some success; for example, advancing of planting date of paddy rice (Oryza sativa) in India significantly reduced soil population densities of $R$. reniformis $(6,38)$. The use of soil solarization was effective in reducing the population density of $R$. reniformis, but its use is very expensive and is not feasible for a pulse crop (66).

Other nematode parasites reported to infect chickpea comprise a long list of migratory ectoparasites, including dagger, needle, pin, ring, spiral, stunt, and stubbyroot nematode species (Table 1). However, pathogenicity to chickpea of all these nematodes has not been demonstrated, except for Helicotylenchus indicus, Tylenchorhynchus brassicae, and Tylenchorhynchus vulgaris $(32,60,78)$. Finally, the oat race of the stem and bulb nematode, Ditylenchus dipsaci, was reported in South Australia to cause severe yield losses in young chickpea plants, whereas adult plants were resistant to the nematode (77).

\section{Diagnosis of Nematodes Pathogenic to Chickpea}

The accurate identification of plantparasitic nematodes infecting crops is a prerequisite for designing effective management strategies. This is particularly relevant for chickpea, where several species of Meloidogyne, Heterodera, and Pratylenchus have been reported to be pathogenic to chickpea in several growing areas. Identification of these species is mostly based on morphology and morphometric traits of adult females or cysts (57), but such a task is hindered by the intra-specific variability of morphological traits and the need for experienced diagnosticians. Diagnostic characteristics differentiating Meloidogyne spp. include the tail shape and length of $\mathrm{J} 2$ juveniles (Fig. $10 \mathrm{E}$ to $\mathrm{H}$ ) and the characteristic perineal pattern of adult females (Fig. 10A to D) The perineal pattern of $M$. artiellia is typical, showing a very distinct inner area which contains the vulva and anus that is surrounded by a few coarse lines arranged 
in a figure-eight with a large base and a small top (Fig. 10B). Similarly, the tail shape and length of the $\mathrm{J} 2$ in $M$. artiellia is typically rounded and short compared with those of other species infecting chickpea (Fig. 10E to H).

Reliable diagnostic methods based on protein or nucleic acid analyses are now available and have significantly improved the routine identification of Meloidogyne species. Analysis of isozyme electrophoretic patterns proved valuable in separating Meloidogyne spp. damaging chickpea $(17,29)$ (Fig. 11). The esterase pattern of $M$. artiellia revealed a characteristic twoband phenotype, M2, (Fig. 11) which can be clearly differentiated from phenotypes of other root-knot nematodes infecting chickpea, viz. M. arenaria (A1, A2, or A3 phenotypes), $M$. incognita (I1 phenotype), and M. javanica (J3 phenotype) (Fig. 11). Similarly, the malate dehydrogenase phenotype of $M$. artiellia revealed a weak band with higher relative mobility than those phenotypes of other root-knot nematodes infecting chickpea (Fig. 11). In addition, several DNA-based analyses have been successfully used for the diagnosis of Meloidogyne spp. damaging chickpea, including polymerase chain reaction (PCR) assays using primers derived from sequence characterized amplified regions (SCAR), restriction fragment length polymorphisms (RFLP) of the internal transcribed spacer (ITS), and phylogenetic studies of the 18S, ITS1-5.8S-ITS2, and D2-D3 region of $28 \mathrm{~S}$ of ribosomal DNA (rDNA) sequences $(17,86)$.

Identification of root-lesion nematodes, Pratylenchus spp., is based on morphology and morphometric traits of adult females and males, of which the number of lip annuli, presence of males, stylet length, shape of spermatheca, and position of vulva and post-vulval uterine sac are particularly important diagnostic characters $(15,46)$. Although morphology continues to be the basis for the identification of Pratylenchus spp., new technologies based on biochemical and molecular analyses are also becoming increasingly important for practical identifications and phylogenetic studies $(1,2,5,8,19)$. Andrés et al. (5) found that species-specific isozyme phenotypes obtained by isoelectrofocusing successfully differentiated some Pratylenchus species infecting chickpeas, such as $P$. brachyurus, $P$. neglectus, $P$. penetrans, and P. thornei. Similarly, Carrasco-Ballesteros et al. (8) developed a pair of SCAR primers specific to $P$. thornei and identified repetitive sequences (satDNA) in $P$. thornei, which can easily be amplified from DNA extracts obtained from different life stages of the nematode. Similarly, although the identification of cyst nematodes attacking chickpea is primarily based on the morphology of cuticle surrounding the vulva in the mature cyst (fenestral patterns), molecular identification of ITS1 and ITS2 sequences, as well as RFLP profiles generated by different restriction enzymes, may help with the identification of $H$. ciceri $(47,74,75)$. Finally, identification of Rotylenchulus species is based mainly on morphological characters of vermiform females, but sequences from the 18S, ITS1-5.8S-ITS2, and D2-D3 of $28 \mathrm{~S}$ rDNA from $R$. reniformis are also available in the GenBank database and may help with the specific identification of this nematode.

\section{Interactions with Rhizobia and Phytopathogenic Fungi}

Plant-parasitic nematodes attacking chickpea may develop complex interrelationships with soilborne microorganisms occupying a similar ecological niche in the chickpea rhizosphere, including beneficial (symbiotic) and deleterious (pathogenic) plant-associated microorganisms. These nematode interactions are important biological and phytopathological phenomena of great significance for chickpea production.

Free nitrogen fixation by chickpea roots through effective symbiotic association with Mesorhizobium and Sinorhizobium rhizobia can enable cultivation of the crop in many nitrogen-poor soils (55). Yield potential of chickpea depends on the associated rhizobia and plant genotype that together influence the symbiotic performance and the symbiosis response to biotic and abiotic stresses (73). Nematode parasitism may influence symbiotic nodulation on legumes roots by associated rhizobia and thus nitrogen fixation (40). Studies in greenhouse conditions showed that $M$. incognita infected more than $25 \%$ of nodules induced by Mesorhizobium in chickpea cv. UC 648 (84). Moreover, histological observations of the nematode-infected nodules showed that $\mathbf{J} 2$ had established permanent feeding sites in the vascular bundles of the nodules and induced the formation of giant cells (Fig. 12). Disruption of xylem elements was associated with enlargement of the nematode body and expansion of giant cells. However, the integrity of bacteroids inside the nodule was not affected by the nematode infection. Although the development of nodules was apparently not suppressed by nematode infection, histological examination of
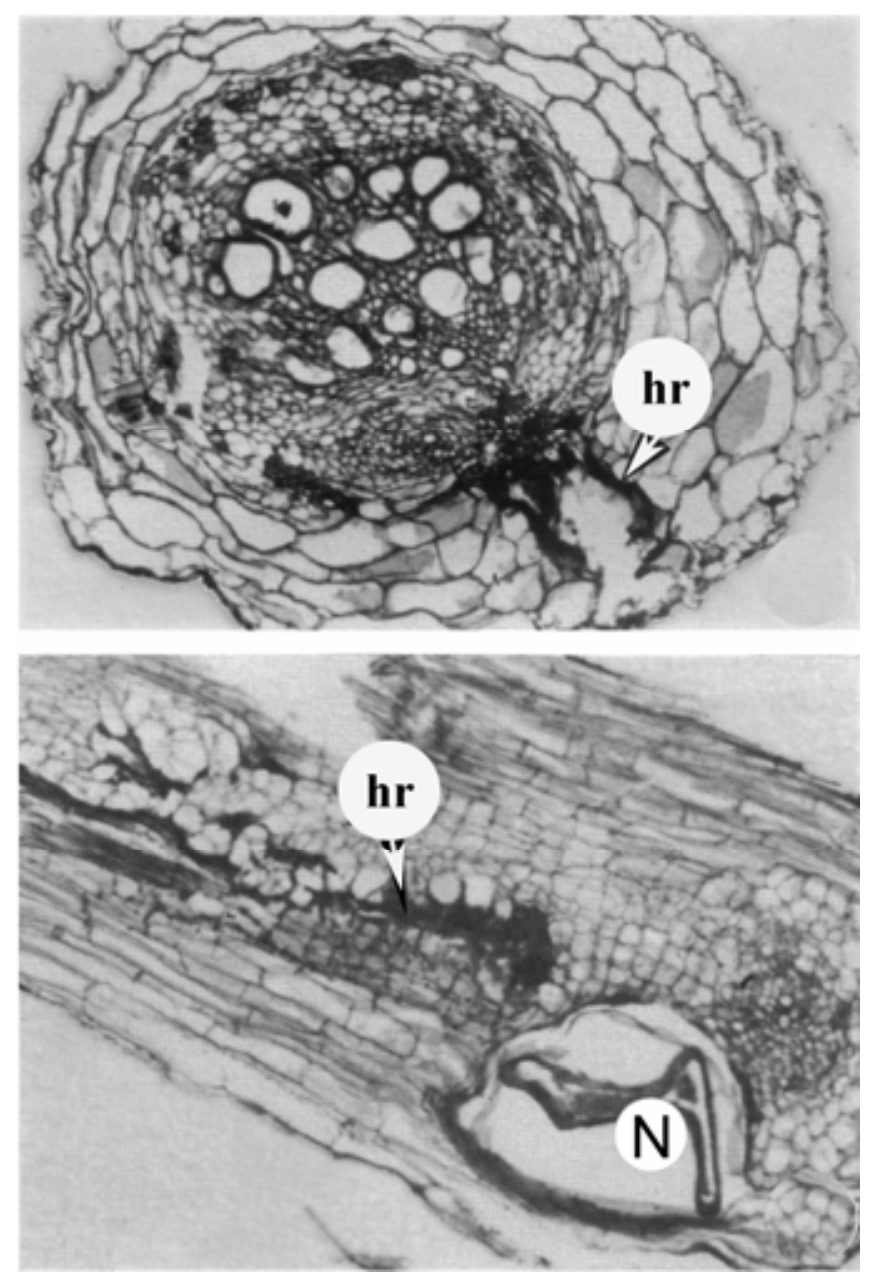

Fig. 8. Histopathological observations showing the reaction of a resistant wild chickpea accession (Cicer reticulatum) to Heterodera ciceri showing the absence of syncytia formation and hypersensitive reaction (hr) with necrosis of several root cells surrounding the nematode juvenile $(\mathrm{N})$. 
infected tissues suggested premature senescence (84). Other studies have shown that rhizobial nodulation can be impaired by parasitism by root-knot nematodes; for example, $M$. incognita and $M$. javanica significantly decreased the number of functional nodules per root system on several chickpea cultivars $(50,54,82)$. Also, infections of chickpea by $P$. thornei or $R$. reniformis induced a reduction in the number of nodules formed on infected roots compared with that formed in uninfected ones $(18,79)$.

Nematode parasitism plays a significant role in the development of other chickpea diseases caused by soilborne pathogens. Interactions between plant-parasitic nematodes and fungi can vary considerably over plant genotypes, cultivars, and lines, as indicated in studies of disease complexes on multiple chickpea genotypes $(7,11$, $12,81)$. In fact, a number of comprehensive studies have been carried out concerning interactions between plant-parasitic nematodes, including Pratylenchus spp. and Meloidogyne spp., and pathogenic fungi, mainly $F$. oxysporum f. sp. ciceris, the causal agent of Fusarium wilt of chickpea $(7,11,12,81)$.

Management of Fusarium wilt in chickpea is mainly by the use of race-specific resistance, which is widely recognized as the safest, most economical, and most effective control method for the disease $(41,45,53)$. Studies in India have shown that interactions of $F$. oxysporum $\mathrm{f}$. sp. ciceris and $M$. incognita or $M$. javanica in chickpea can lead to a breakdown in the resistance in chickpea plants against an unidentified race of the Fusarium wilt
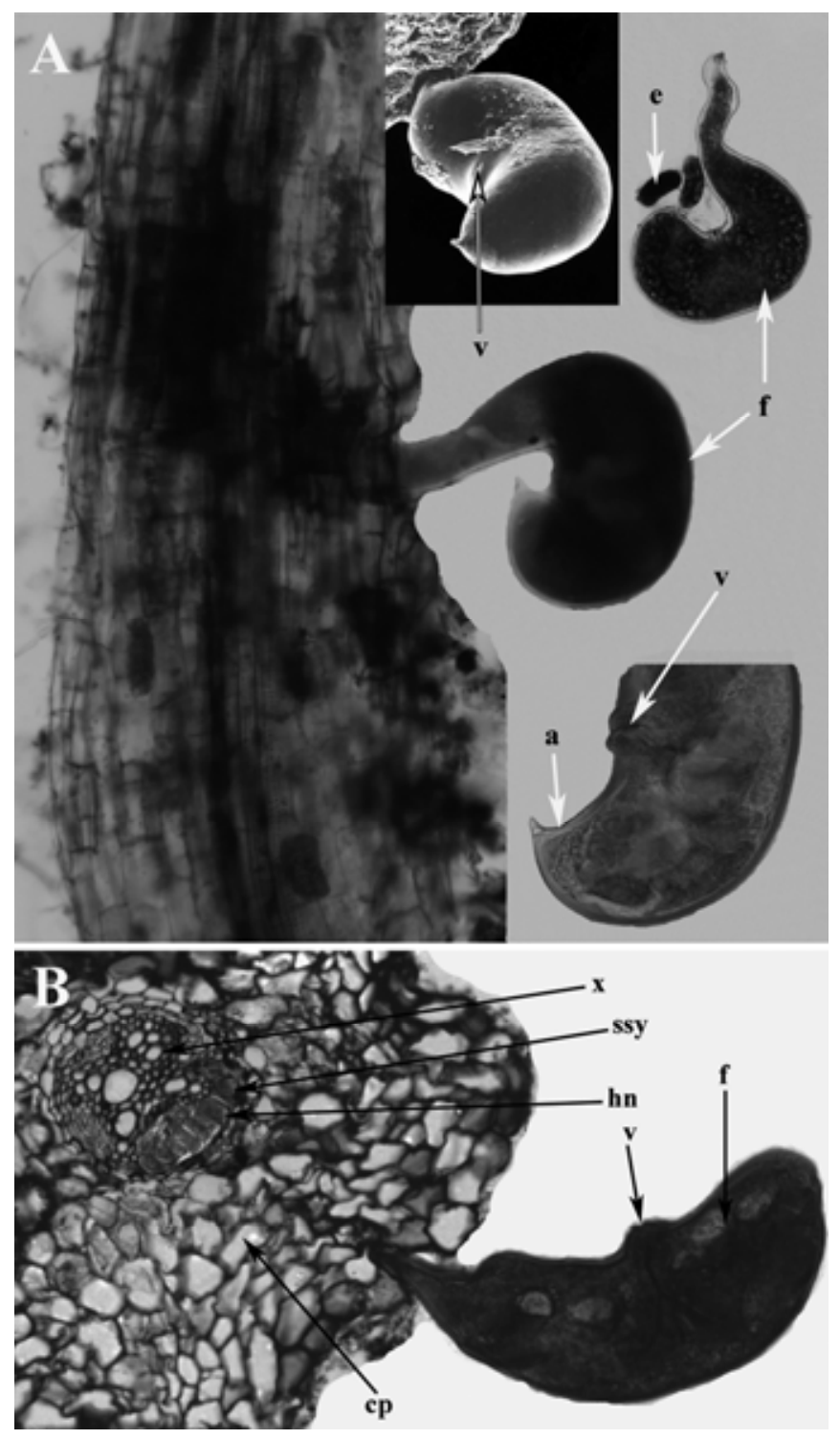

Fig. 9. A, Mature females (f) of the reniform nematode Rotylenchulus reniformis infecting chickpea roots showing details of vulva (v), anus (a), and deposited egg (e). B, Histopathological observations of the permanent feeding site induced by $R$. reniformis showing enlarged endodermal cells forming the stelar syncytium (ssy) with hypertrophied nuclei $(\mathrm{hn})$, distorting the xylem tissue (x), and showing the anterior part of the body embedded in the cortical parenchyma (cp).

pathogen $(44,51,80,81)$. Similarly, in Spain, results from growth chamber experiments with moderate and high fungal inoculum densities clearly demonstrated that in chickpea genotypes with partial resistance to Fusarium wilt, the severity of the disease was significantly increased by coinfection with $F$. oxysporum f. sp. ciceris race 5 and $M$. artiellia (Fig. 13) (12). This effect occurred regardless of the fungal inoculum density and the geographic origin of $M$. artiellia (Italy or Syria), except for cultivar CPS 1 , in which a significant increase in Fusarium wilt severity occurred only with the highest fungal inoculum density (12). Moreover, results from those experiments suggested that coinfection by the two pathogens can overcome complete resistance to $F$. oxysporum f. sp. ciceris race 5 in some chickpea genotypes (e.g., lines CA 334.20.4, CA 336.14.3.0, and UC 27), but not in others (line ICC $14216 \mathrm{~K}$ ), and that the breakdown of such resistance occurs irrespective of the initial inoculum density of the fungus and the geographic origin of the nematode (e.g., lines CA 334.20.4, and CA 336.14.3.0), or require a high inoculum density of $F$. oxysporum $\mathrm{f}$. sp. ciceris race 5 (cv. UC 27) (Fig. 13) (12). Interestingly, this genotype-specific resistance breakdown by $M$. artiellia infection did not occur for other pathogenic races of $F$. oxysporum f. sp. ciceris such as races $0,1 \mathrm{~A}$, and 2 . Thus, stability of Fusarium wilt resistance in genotypes with complete resistance (e.g., lines BG-212, CA 334.20.4, CA 336.14.3.0, ICC $1416 \mathrm{~K}$, PV 61, UC 27, and WR-315) or complete susceptibility (line P 2245) to these races of $F$. oxysporum f. sp. ciceris was not compromised by coinfection of the plant with both pathogens (P. Castillo, unpublished results).

Conversely, simultaneous or sequential coinfection of chickpea by $P$. thornei and $F$. oxysporum f. sp. ciceris race 5 did not modify severity of Fusarium wilt in chickpea genotypes susceptible to wilt (11). However, coinfection of roots following inoculations with 5 nematodes per $\mathrm{cm}^{3}$ and 5,000 chlamydospores per $g$ of soil resulted in significantly higher numbers of propagules of the fungus in wilt-susceptible cv. CPS 1 but not in wilt-resistant cv. UC 27. Such a difference in responses of chickpea genotypes was reduced by increasing the nematode inoculum to 10 nematodes per $\mathrm{cm}^{3}$ of soil, which resulted in a significant increase of root infection by $F$. oxysporum f. sp. ciceris race 5 in both cultivars irrespective of fungal inoculum densities ( 250 or 2,000 chlamydospores per g of soil) (11).

\section{Concluding Remarks}

Attacks by root-knot, root-lesion, and cyst-forming nematodes can significantly limit chickpea production worldwide, particularly in subsistence agriculture. Although the extent of crop yield loss is 
mainly determined by the nematode population density in soil, other factors in the agro-ecosystem (e.g., climate, soil conditions, cultivar susceptibility, etc.) may also contribute to significant yield reductions.
Accurate and quick diagnoses of the nematode species and pathogenic variants are a prerequisite for the proper management of nematodes in chickpea. While conventional identification of nematodes based on their morphological features can be hindered by insufficient expertise of diagnosticians, the use of newly developed diagnosis technologies based on biochemical and DNA analyses can be of help. Man-

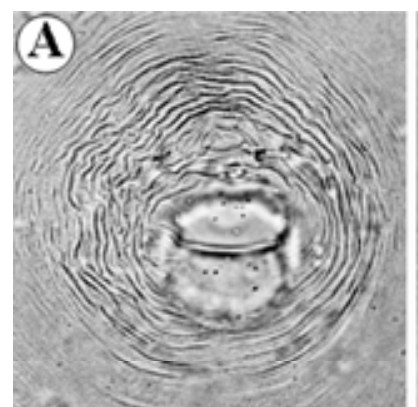

M. arenaria

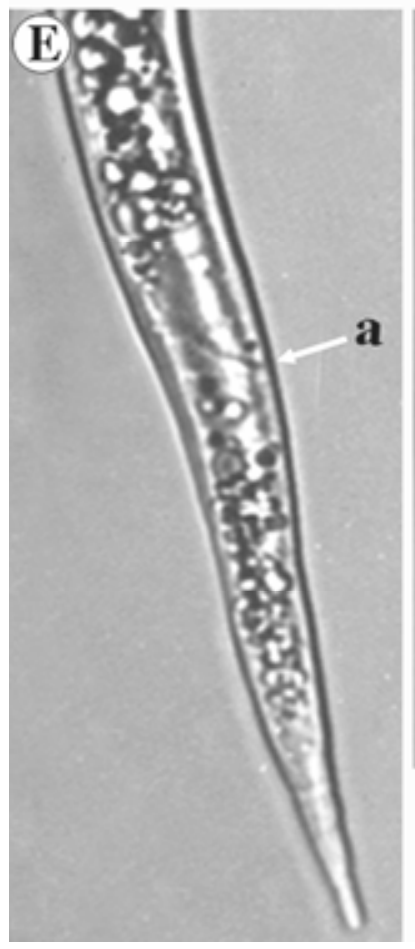

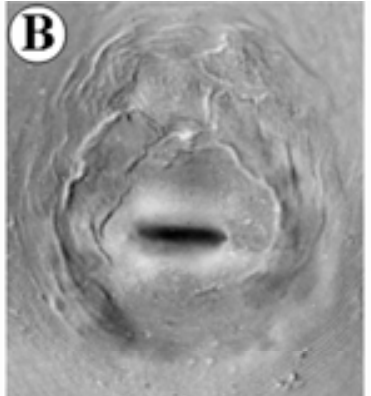

M. artiellia


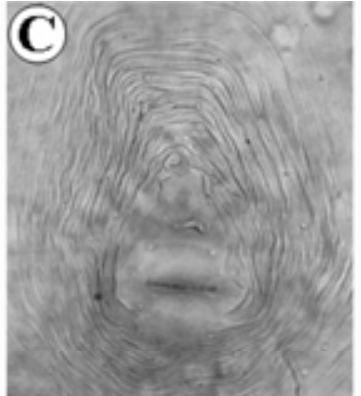

M. incognita
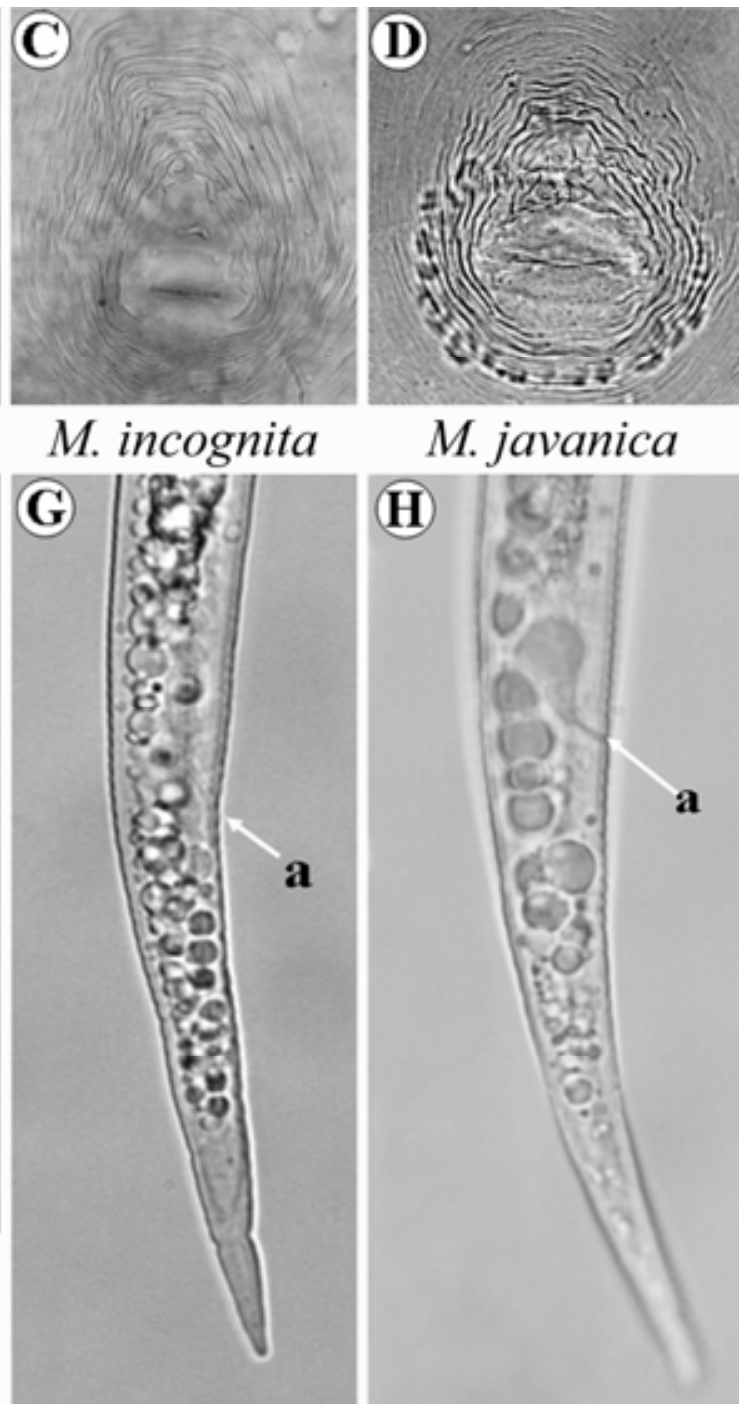

\section{M. javanica}



Fig. 10. A-D, Micrographs showing differences among the female perineal patterns, and E-H, second-stage juvenile tails of root-knot nematodes attacking chickpea. A, E, Meloidogyne arenaria; B, F, M. artiellia; C, G, M. incognita; D, H, M. javanica. Abbreviation: a = anus.
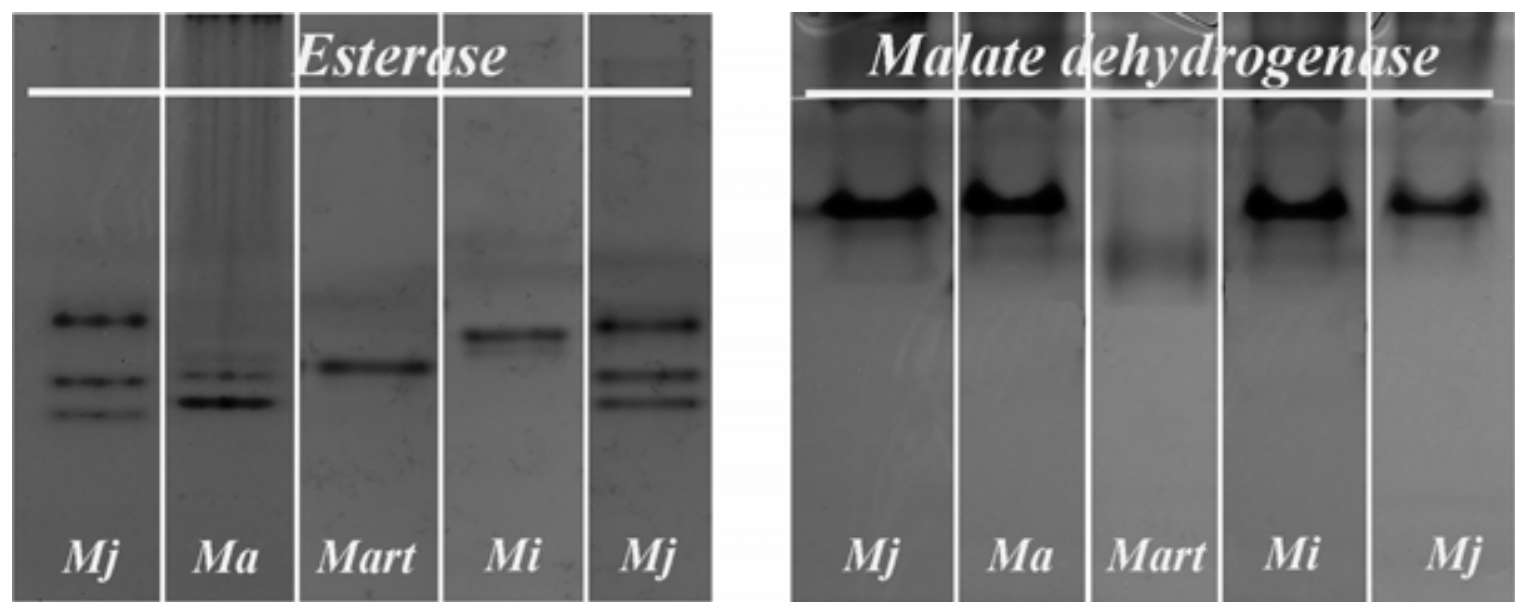

Fig. 11. Esterase and malate dehydrogenase electrophoresis patterns of protein homogenates from five young, egg-laying females of root-knot nematode species attacking chickpea: Ma = Meloidogyne arenaria; Mart = M. artiellia; Mi = M. incognita; and Mj = M. javanica. 



Fig. 12. Longitudinal sections of Mesorhizobium-chickpea (cv. UC 648) nodules infected by Meloidogyne incognita showing the arrangement of vascular bundles (vb), the differentiating bacteroid zone (db), and the nematode feeding site (fs) induced by the mature female $(\mathrm{N})$ in the Mesorhizobium nodule. agement of nematodes that attack chickpea must be based on strategies that integrate the use of available host resistance or tolerance in chickpea cultivars together with crop rotation and cultural modifications that can be practiced by farmers (e.g., time of planting). Practical and efficient integrated management of plant-parasitic nematodes in chickpea requires that high-yielding cultivars with appropriate marketable traits and resistance or tolerance to nematodes be made available to farmers. Additional studies are also needed to improve cultural management practices. Finally, further studies are needed to unravel mechanisms underlying the interactions between Meloidogyne species and races of $F$. oxysporum f. sp. ciceris. Such information would foster appropriate use of the wilt-resistant cultivars in chickpea fields infested with the two pathogens.

\section{Acknowledgments}

Original results from the authors reported in this article were derived from research supported by grants (AGL2003-0640, AGL2004-01231) from Dirección General de Investigación, Ministerio de

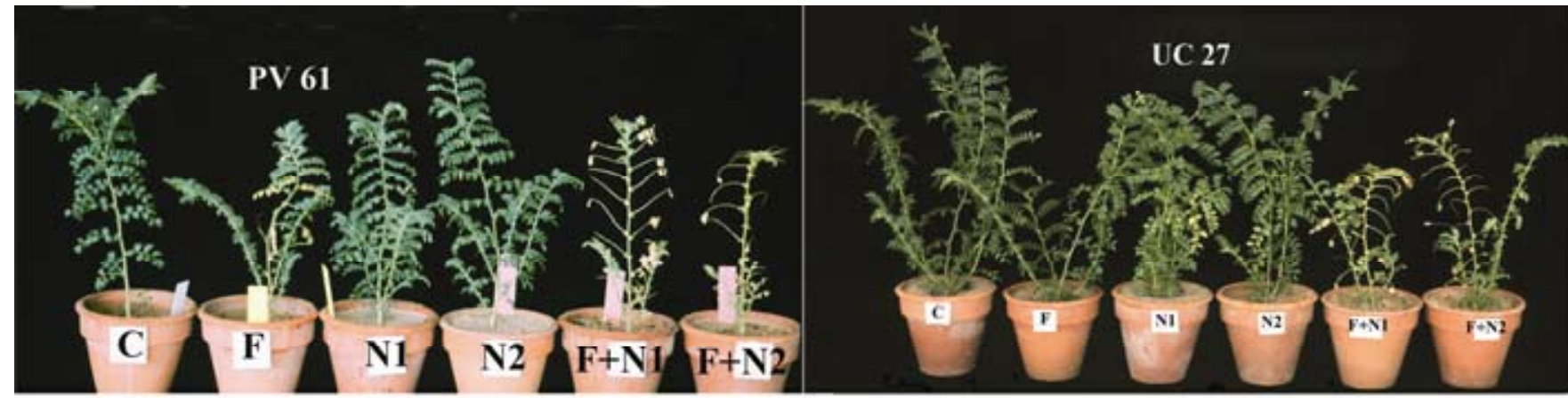

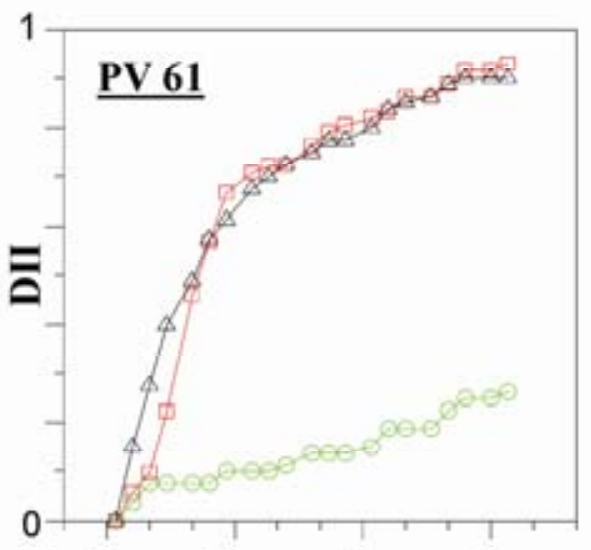

$\begin{array}{lll}15 & 30 & 45\end{array}$

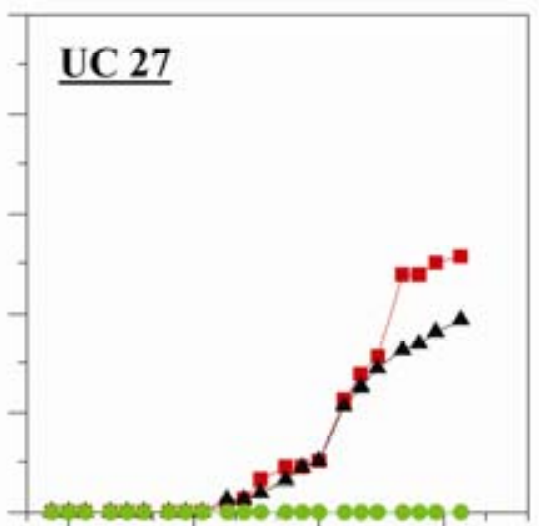

15

60
$-$

Treatments

- Foc 3,000 CFU/g

- Foe $30,000 \mathrm{CFU} / \mathrm{g}$

—_ Foe 3,000 CFU/g + Ma-S

- Foc $30,000 \mathrm{CFU} / \mathrm{g}+\mathrm{Ma}-\mathrm{S}$

$\triangle$ Foc 3,000 CFU/g + Ma-I

A- Foc 30,000 CFU/g + Ma-I

15

\section{ICC $14216 \mathrm{~K}$}

Time (No. of days after inoculation)

Fig. 13. Symptoms of Fusarium wilt in chickpea genotypes with partial (cv. PV 61) and complete (cv. UC 27 and line ICC 14216 K) resistance to Fusarium oxysporum f. sp. ciceris race 5. Progress of disease intensity index (DII) in chickpea genotypes simultaneously inoculated with 3,000 or 30,000 chlamydospores/g soil and Meloidogyne artiellia populations from Italy (Ma-I) and Syria (MaS) (20 eggs and second-stage juveniles $/ \mathrm{cm}^{3}$ soil). Abbreviations: $C=$ uninoculated control plants; $F=$ plants inoculated with the fungus only; N1 = plants inoculated with a population of $M$. artiellia from Italy only; N2 = plants inoculated with a population of $M$. artiellia from Syria only; $\mathrm{F}+\mathrm{N} 1$ = plants simultaneously inoculated with the fungus and a population of $M$. artiellia from Italy; and $\mathrm{F}+$ N2 = plants simultaneously inoculated with the fungus and a population of $M$. artiellia from Syria. 
Educación y Ciencia, Spain. We would like to express our gratitude to two anonymous reviewers and the editor for improving the manuscript, and to J. Martín Barbarroja and J. M. León Ropero from IAS-CSIC for technical assistance.

\section{Literature Cited}

1. Al-Banna, L., Ploeg, A. T., Williamsom, V. M., and Kaloshian, I. 2004. Discrimination of six Pratylenchus species using PCR and speciesspecific primers. J. Nematol. 36:142-146.

2. Al-Banna, L., Williamsom, V., and Gadner, S. L. 1997. Phylogenetic analysis of nematodes of the genus Pratylenchus using nuclear 26S rDNA. Mol. Phylogenet. Evol. 7:94-102.

3. Ali, S. S. 1995. Nematode problems in chickpea. Indian Institute of Pulses Research, Kanpur, India.

4. Ali, S. S., and Sharma, S. B. 2003. Nematode survey of chickpea production areas in Rajasthan, India. Nematol. Mediterr. 31:147-149.

5. Andrés, M. F., Pinochet, J., Hernández-Dorrego, A., and Delibes, A. 2000. Detection and analysis of inter and intraspecific diversity of Pratylenchus spp. using isozyme markers. Plant Pathol. 49:640-649.

6. Anonymous 1988. Indian Agricultural Research Institute. Annual Report, Nematology, 68-70.

7. Bhatt, J., and Vadhera, I. 1997. Histopathological studies on cohabitation of Pratylenchus thornei and Rhizoctonia bataticola on chickpea (Cicer arietinum L.). Adv. Plant Sci. 10:33-38.

8. Carrasco-Ballesteros, S., Castillo, P., Adams, B. J., and Pérez-Artés, E. 2007. Identification of Pratylenchus thornei, the cereal and legume root-lesion nematode, based on SCAR-PCR and satellite DNA. Eur. J. Plant Pathol. 118:115-125

9. Castillo, P., Gómez-Barcina, A., and JiménezDíaz, R. M. 1996. Plant parasitic nematodes associated with chickpea in southern Spain and effect of soil temperature on reproduction of Pratylenchus thornei. Nematologica 42:211219.

10. Castillo, P., Jiménez Díaz, R. M., GomezBarcina, A., and Vovlas, N. 1995. Parasitism of the root-lesion nematode Praylenchus thornei on chickpea. Plant Pathol. 44:728-733.

11. Castillo, P., Mora-Rodríguez, M. P., NavasCortés, J. A., and Jiménez-Díaz, R. M. 1998. Interactions between Pratylenchus thornei and Fusarium oxysporum f. sp. ciceris on chickpea. Phytopathology 88:836-844.

12. Castillo, P., Navas-Cortés, J. A., Gomar Tinoco, D., Di Vito, M., and Jiménez-Díaz, R. M. 2003. Interactions between Meloidogyne artiellia, the cereal and legume root-knot nematode, and Fusarium oxysporum f. sp. ciceris race 5 in chickpea. Phytopathology 93:1513-1523.

13. Castillo, P., Rapoport, H. F., Palomares Rius, J. E., and Jiménez Díaz, R. M. 2008. Suitability of weeds species prevailing in Spanish vineyards as hosts for root-knot nematodes. Eur. J. Plant Pathol. 120:43-51.

14. Castillo, P., Trapero-Casas, J. L., and JiménezDíaz, R. M. 1996. The effect of temperature on hatching and penetration of chickpea roots by Pratylenchus thornei. Plant Pathol. 45:310315.

15. Castillo, P., and Vovlas, N. 2007. Pratylenchus (Nematoda: Pratylenchidae): Diagnosis, Biology, Pathogenicity and Management. Brill, Leiden, Netherlands.

16. Castillo, P., Vovlas, N., and Jiménez-Díaz, R. M. 1998. Pathogenicity and histopathology of Pratylenchus thornei populations on selected chickpea genotypes. Plant Pathol. 47:370-376.

17. Castillo, P., Vovlas, N., Subbotin, S., and Troccoli, A. 2003. A new root-knot nematode,
Meloidogyne baetica n. sp. (Nematoda: Heteroderidae), parasitizing wild olive in Southern Spain. Phytopathology 93:1093-1102.

18. Darekar, K. S., and Jagdale, G. B. 1987. Pathogenicity to Rotylenchulus reniformis to chickpea. Curr. Res. Rep. Mahatma Phule Agric. Univ. 3:89-91.

19. De Luca, F., Fanelli, E., Di Vito, M., Reyes, A., and De Giorgi, C. 2004. Comparison of the sequences of the D3 expansion of the $26 \mathrm{~S}$ ribosomal genes reveals different degrees of heterogeneity in different populations and species of Pratylenchus from the Mediterranean region. Eur. J. Plant Pathol. 110:949-957.

20. Di Vito, M., and Greco, N. 1988. The relationship between initial population densities of Meloidogyne artiellia and yield of winter and spring chickpea. Nematol. Mediterr. 16:163166.

21. Di Vito, M., and Greco, N. 1988. Investigation on the biology of Meloidogyne artiellia. Rev. Nématol. 11:221-225.

22. Di Vito, M., Greco, N., Halila, H. M., Mabsoute, L., Labdi, M., Beniwal, S. P. S., Saxena, M. C., Singh, K. B., and Solh, M. B. 1994. Nematodes of cool-season food legumes in North Africa. Nematol. Mediterr. 22:3-10.

23. Di Vito, M., Greco, N., Oreste, G., Saxena, M. C., Singh, K. B., and Kusmenoglu, I. 1994. Plant parasitic nematodes of legumes in Turkey. Nematol. Mediterr. 22:245-251.

24. Di Vito, M., Greco, N., and Saxena, M. C. 1992. Pathogenicity of Pratylenchus thornei on chickpea in Syria. Nematol. Mediterr. 20:71-73

25. Di Vito, M., Greco, N., and Zaccheo, G. 1985. On the host range of Meloidogyne artiellia. Nematol. Mediterr. 13:207-212.

26. Di Vito, M., Singh, K. B., Greco, N., and Saxena, M. C. 1996. Sources of resistance to cyst nematode in cultivated and wild Cicer species. Genet. Res. Crop Evol. 43:103-107.

27. Edwards, E. E. 1956. Studies on resistance to the root-knot nematode of the genus Meloidogyne Goeldi, 1887. Proc. Helminthol. Soc. Wash. 23:112-118.

28. Eisenback, J. D., and Triantaphyllou, H. H. 1991. Root-Knot nematodes: Meloidogyne species and races. Pages 191-274 in: Manual of Agricultural Nematology. W. R. Nickle, ed. Marcel Dekker, Inc., New York.

29. Esbenshade, P. R., and Triantaphyllou, A. C. 1985. Use of enzyme phenotypes for identification of Meloidogyne (Nematoda: Tylenchida). J. Nematol. 17:6-20

30. Food and Agriculture Organization of the United Nations statistical database (FAOSTAT). 2007. Faostat production statistics of crops. Online database, http://faostat.fao.org/

31. Fortuner, R. 1977. Pratylenchus thornei. CIH Descriptions of Plant-Parasitic Nematodes, Set 7, No. 93. St. Albans, UK, Commonwealth Agricultural Bureaux.

32. Gill, J. S., and Swarup, G. 1977. Pathogenic effect of Tylenchorhynchus vulgaris on gram. Indian J. Nematol. 7:155-156.

33. Glazer, J., and Orion, D. 1983. Studies on anhydrobiosis of Pratylenchus thornei. J. Nematol. 15:333-338

34. Greco, N., Di Vito, M., and Nombela, G. 1992. The emergence of juveniles of Heterodera $\mathrm{ci}$ ceri. Nematologica 38:514-519.

35. Greco, N., Di Vito, M., Saxena, M. C., and Reddy, M. V. 1988. Effect of Heterodera ciceri on yield of chickpea and lentil and development of this nematode on chickpea in Syria. Nematologica 34:98-114

36. Greco, N., Di Vito, M., Saxena, M. C., and Reddy, M. V. 1988. Investigation on the root lesion nematode Pratylenchus thornei in Syria. Nematol. Mediterr. 16:101-105.

37. Greco, N., Vovlas, N., and Inserra, R. N. 1992. The chickpea cyst nematode, Heterodera $\mathrm{ci}$ - ceri. Nematology Circular Florida Department Agriculture 198.

38. Haidar, M. G., Askary, T. H., and Nath, R. P. 2001. Nematode population as influenced by paddy based cropping sequences. Indian $\mathrm{J}$. Nematol. 31:68-71.

39. Hernández Fernández, V., Martín Barbarroja, J., Jiménez Díaz, R. M., and Castillo, P. 2005. Reproductive fitness of Meloidogyne artiellia populations on chickpea and durum wheat. Nematology 7:243-247.

40. Hussey, R. S., and McGuire, J. M. 1987. Interaction with other organisms. Pages 294-328 in: Principles and practice of nematode control in crops. R. H. Brown and B. R. Kerry, eds. Academic Press, London.

41. Jiménez-Díaz, R. M., Porta-Puglia, A., and Tivoli, B. 1998. New approaches in the integrated management of legume diseases: Toward sustainable crop health. Pages 89-93 in: Eur. Conf. Grain Legumes, 3rd. Opportunities for High Quality, Healthy and Added-Value Crops to Meet European Demands. European Association for Grain Legumes, ed. Valladolid, Spain.

42. Kaloshian, I., Greco, N., Saad, A. T., and Vovlas, N. 1986. Life cycle of Heterodera cicer on chickpea. Nematol. Mediterr. 14:135-145.

43. Kornobis, S., and Wolny, S. 1997. Occurrence of plant parasitic nematodes on weeds in agrobiocenosis in the Wielkopolska region in Poland. Fund. Appl. Nematol. 20:627-632.

44. Krishna Rao, V., and Krishnappa, K. 1996 Interaction of Fusarium oxysporum $\mathrm{f}$. sp. $\mathrm{ci}$ ceri with Meloidogyne incognita on chickpea in two soil types. Indian Phytopathol. 49:142 147.

45. Landa, B. B., Navas-Cortés, J. A., and Jiménez-Díaz, R. M. 2004. Integrated management of Fusarium wilt of chickpea combining the use of choice of sowing date, host resistance, and biological control. Phytopathology 94:946-960.

46. Loof, P. A. A. 1991. The Family Pratylenchidae Thorne, 1949. Pages 363-421 in: Manual of Agricultural Nematology. W. R. Nickle, ed. Marcel Dekker, Inc., New York.

47. Madani, M., Vovlas, N., Castillo, P., Subbotin, S. A., and Moens, M. 2004. Molecular characterization of cyst nematode species (Heterodera spp.) from the Mediterranean Basin using RFLPs and sequences of ITS-rDNA. J. Phytopathol. 152:229-234.

48. Mahapatra, B. C., and Pahdi, N. N. 1986. Pathogenicity and control of Rotylenchulus reniformis on Cicer arietinum. Nematol. Mediterr. 14:287-290.

49. Malhotra, R. S., Singh, K. B., Di Vito, M. Greco, N., and Saxena, M. C. 2002. Registration of ILC 10765 and ILC 10766 chickpea germplasm lines resistant to cyst nematode. Crop Sci. 42:1756.

50. Mani, A., and Sethi, C. L. 1984. Plant growth of chickpea as influenced by initial inoculum levels of Meloidogyne incognita. Indian $\mathrm{J}$. Nematol. 14:41-44.

51. Mani, A., and Sethi, C. L. 1987. Interaction of root-knot nematode, Meloidogyne incognita with Fusarium oxysporum f. sp. ciceris and $F$ solani on chickpea. Indian J. Nematol. 17:1-6.

52. Nath, R. P., Banerjee, A. K., Haider, M. G. I., and Singh, B. K. 1979. Studies on the nematodes of pulse crops in India. I. Pathogenicity of Meloidogyne incognita on gram. Indian Phytopathol. 32:28-31.

53. Navas-Cortés, J. A., Hau, B., and JiménezDíaz, R. M. 1998. Effect of sowing date, host cultivar, and race of Fusarium oxysporum f. sp. ciceris on development of Fusarium wilt of chickpea. Phytopathology 88:1338-1346.

54. Nejad, S. A. H., and Khan, M. W. 1997. Influence of initial inoculum levels of root-knot nematode, Meloidogyne incognita (race-1), on growth of some chickpea cultivars. Appl. Ento- 


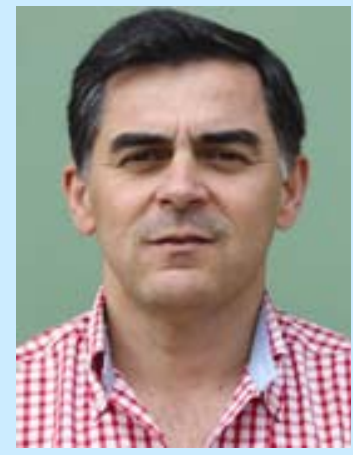

Pablo Castillo



Juan A. Navas-Cortés

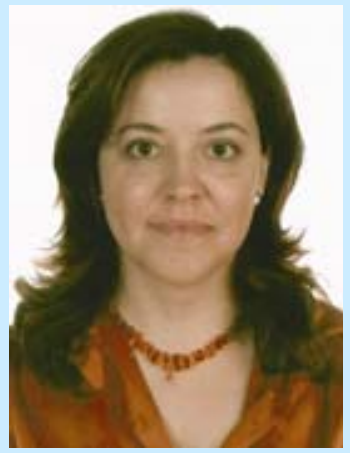

Blanca B. Landa

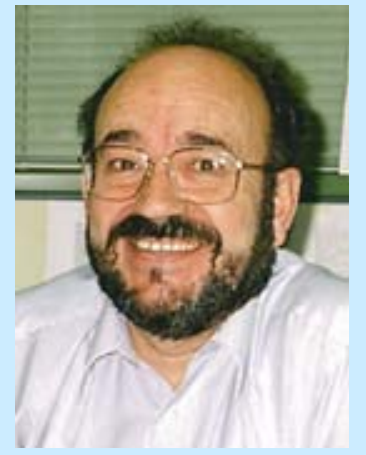

Rafael M. Jiménez-Díaz



Nicola Vovlas
Dr. Castillo is a research scientist at the Institute of Sustainable Agriculture of the Spanish Council for Scientific Research at Córdoba, southern Spain. He received his B.S. (1984) and Ph.D. (1988) from University of Granada (Spain). His research focuses primarily on plant-nematode and nematode-soilborne fungi interactions, as well as diagnosis of nematode diseases, hostparasite relationships, and nematode control by means of strategies compatible with sustainable agriculture. He has contributed to plant nematology with numerous research articles, and recently coauthored two comprehensive books on the spiral nematode genus Rotylenchus and the root-lesion nematode genus Pratylenchus.

Dr. Navas-Cortés is a tenure plant pathologist at the Institute of Sustainable Agriculture, Spanish Council for Scientific Research. He received his B.S. degree and $\mathrm{Ph}$.D. degree in biology from the University of Córdoba in 1986 and 1992, respectively. He was a visiting fellow at the Institute of Plant Diseases and Plant Protection, University of Hannover, Germany in 1994 and 1995. His research activity focuses on the ecology of plant pathogenic fungi, and epidemiology and integrated control of plant diseases in sustainable agriculture. His main area of expertise is quantitative epidemiology, including modeling and spatio-temporal analysis of plant disease epidemics.

Dr. Landa is a tenure plant pathologist at the Institute of Sustainable Agriculture, Spanish Council for Scientific Research. She received a B.S. degree in agriculture engineering and $\mathrm{PhD}$. degree in plant pathology from the University of Córdoba in 1995 and 1999, respectively. She was a postdoctoral Fulbright scholar at the USDAARS, Washington State University, Pullman, USA in 2000 and 2001; and research scientist and assistant professor at the University of Córdoba from 2002 to 2007. Her research activity focuses on population biology of soilborne plant pathogens and rhizosphere biocontrol agents, defining the biogeography, genetic diversity, biology, and ecology of phytopathogenic fungi, plant parasitic nematodes, and plant-associated rhizosphere bacteria with potential as biocontrol agents.

Dr. Jiménez-Díaz is a professor of plant pathology at the University of Córdoba with a joint appointment as a research professor at the Institute of Sustainable Agriculture of the Spanish Council for Scientific Research. He graduated from the Polytechnic University of Madrid in 1969 and the Department of Plant Pathology Cornell University in 1976, and was elected a Fellow of the American Phytopathological Society in 1999. He has been head of the Department of Plant Pathology, University of Córdoba, and Director of the Institute of Sustainable Agriculture. His research program focuses primarily on the ecology and population biology of soilborne fungi and the integrated management of soilborne diseases, with emphasis on Fusarium wilt and Verticillium wilt diseases.

Dr. Vovlas is research leader at the Istituto per la Protezione delle Piante, C.N.R., Bari, Italy, monographically dedicated to plant nematology. His research interests include nematode taxonomy, biology, and hostparasite relationships. Currently, his responsibilities include teaching nematology, taxonomy, biology, and nematode interactions. $\mathrm{He}$ is an active member of the Society of Nematologists, the Organization of Tropical American Nematologists, and the European Society of Nematologists (he also served for 4 years as an active member of the governing board of this society), and currently is on the editorial board of the International Journal of Nematology and Helminthologia. His research activities have resulted in numerous national and international journal articles. He contributed to the CABI Publishing Crop Protection Compendium and recently coauthored two comprehensive monographs. 
mol. Phytopathol. 64:12-13.

55. Nour, S. M., Cleyet-Marel, J. C., Normand, P., and Fernandez, M. P. 1995. Genotypic heterogeneity of strains nodulating chickpea (Cicer arietinum L.) and description of Rhizobium mediterraneum sp. Nov. Int. J. Syst. Bacteriol. 45:640-648.

56. Oteifa, B. A. 1987. Nematode problems of winter season cereals and food legume crops in the Mediterranean region. Pages 199-209 in: Nematodes Parasitic to Cereals and Legumes in Temperate Semi-arid Regions. M. C. Saxena, R. A. Sikora, and J. P. Srivastava, eds. ICARDA, Syria. Proc. Workshop held at Larnaca, Cyprus, 1-5 March.

57. Perry, R. N., and Moens, M. 2006. Plant Nematology. CABI, Wallingford, England.

58. Rao, V., and Krishnappa, K. 1995. Variation in pathogenicity of Meloidogyne incognita on chickpea at different inoculum densities. Indian J. Nematol. 25:177-180.

59. Rashid, A., Khan, F. A., and Khan, A. M. 1973. Plant parasitic nematodes associated with vegetables, fruits, cereals and crops following infection by Rotylenchulus reniformis. Indian J. Nematol. 3:8-23.

60. Sartaj, A., Verma, T. N., and Alam, M. M. 1999. Inoculum potential of spiral nematode, Helicotylenchus indicus in relation to growth of chickpea. Ann. Plant Prot. Sci. 7:231-233.

61. Sasser, J. N., and Freckman, D. W. 1987. A worldwide perspective on Nematology: The role of the society. Pages 7-14 in: Vistas on Nematology. J. A. Veech and D. W. Dickson, eds. Society of Nematologist, Hyattsville, MD, USA.

62. Saxena, M. C., Greco, N., and Di Vito, M. 1992. Control of Heterodera ciceri by crop rotation. Nematol. Mediterr. 20:75-78.

63. Seinhorst, J. W. 1965. The relationship between nematode density and damage to plants. Nematologica 11:137-154.

64. Sharma, S. B., and McDonald, D. 1990. Global status of nematode problems of groundnut, pigeonpea, chickpea, sorghum and pearl millet, and suggestions for future work. Crop Prot. 9:453-458

65. Sharma, S. B., Mohiuddin, M., Reddy, M. V., Singh, O., and Rego, T. J. 1995. Tolerance in chickpea to Meloidogyne javanica. Fund. Appl. Nematol. 18:197-203.

66. Sharma, S. B., and Nene, Y. L. 1990. Effects of soil solarization on nematodes parasitic to chickpea and pigeonpea. J. Nematol. 22:658664.

67. Sharma, S. B., Siddiqi, M. R., Rahaman, P. F., Ali, S. S., and Ansari, M. A. 1998. Description of Heterodera swarupi sp. n. (Nematoda Heteroderidae), a parasite of chickpea in India. Int. J. Nematol. 8:111-116.

68. Sharma, S. B., Smith, D. H., and McDonald, D. 1992. Nematode constraints of chickpea and pigeonpea production in the semiarid tropics. Plant Dis. 76:868-874.

69. Sikora, R. A., and Fernández, E. 2005. Nematode parasites of vegetables. Pages 319-392 in: Plant Parasitic Nematodes in Subtropical and Tropical Agriculture. M. Luc, R. A. Sikora, and J. Bridge, eds. CABI Publishing, Wallingford, UK.

70. Sikora, R. A., Greco, N., and Veloso Silva, J. F. 2005. Nematode parasites of food legumes. Pages 259-318 in: Plant Parasitic Nematodes in Subtropical and Tropical Agriculture. M. Luc, R. A. Sikora, and J. Bridge, eds. CABI Publishing, Wallingford, UK.

71. Singh, K. B., Di Vito, M., Greco, N., and Saxena, M. C. 1989. Reaction of wild Cicer spp. lines to Heterodera ciceri. Nematol. Mediterr. 17:113-114.

72. Sivakumar, C. V., and Seshadri, A. R. 1971. Life history of the reniform nematode, Rotylenchulus reniformis Linford and Oliveira, 1940. Indian J. Nematol. 1:7-20.

73. Soussi, M., Lluch, C., and Ocaña, A. 1999 Comparative study of nitrogen fixation and carbon metabolism in two chickpea (Cicer arietinum) cultivars under salt stress. J. Exp. Bot. 50:1701-1708.

74. Subbotin, S. A., Vierstraete, A., De Ley, P., Rowe, J., Waeyenberge, L., Moens, M., and Vanfleteren, J. R. 2001. Phylogenetic relationships within the cyst-forming nematodes (Nematoda, Heteroderidae) based on analysis of sequences from the ITS regions of ribosomal DNA. Mol. Phylogenet. Evol. 21:1-16.

75. Subbotin, S. A., Waeyenberge, L., and Moens, M. 2000. Identification of cyst forming nematodes of the genus Heterodera (Nematoda: Heteroderidae) based on the ribosomal DNARFLPs. Nematology 2:153-164

76. Talavera, M., and Valor, H. 2000. Influence of the previous crop on the anhydrobiotic ability of Pratylenchus thornei and Merlinius brevidens. Nematol. Mediterr. 28:77-81.

77. Thompson, J. P., Greco, N., Eastwood, R. Sharma, S. B., and Scurrah, M. 2000. Integrated control of nematodes of cool legumes. Pages 491-506 in: Linking Research and Marketing Opportunities for Pulses in the 21st Century (Proc. Int. Food Legumes Res. Conf. 3rd.). R. Knight, ed. Kluwer Academic Publishers, Dordrecht, The Netherlands.

78. Tiyagi, S. A., and Mashkoor, M. A. 1989. Effect of different inoculum densities of stunt nematode, Tylenchorhynchus brassicae on the growth on chickpea. Int. Chickpea Newsl. 20:14-15.

79. Tiyagi, S. A., and Parveen, M. 1992. Pathogenic effect of root-lesion nematode Pratylenchus thornei on plant growth, water absorption capability, and chlorophyll content of chickpea. Int. Chickpea Newsl. 26:18-20.

80. Uma Maheshwari, T., Sharma, S. B., Reddy, D. D. R., and Haware, M. P. 1995. Co-infection of wilt resistant chickpeas by Fusarium oxysporum f. sp. ciceris and Meloidogyne javanica. J. Nematol. 27:649-653.

81. Uma Maheswari, T., Sharna, S. B., Reddy, D. D. R., and Haware, M. P. 1997. Interaction of Fusarium oxysporum f. sp. ciceris and Meloidogyne javanica on Cicer arietinum. J. Nematol. 29:117-126.

82. Upadhyay, K., and Dwivedi, B. K. 1987. Effect of interaction between Meloidogyne javanica and Fusarium oxysporum f. sp. ciceris on chickpea. Indian J. Nematol. 17:145-146.

83. Vanstone, V. A., and Russ, M. H. 2001. Ability of weeds to host the root lesion nematodes Pratylenchus neglectus and P. thornei I. Grass weeds. Australas. Plant Pathol. 30:245-250.

84. Vovlas, N., Castillo, P., and Troccoli, A. 1998 Histology of nodular tissue of three leguminous hosts infected by three root-knot nematode species. Int. J. Nematol. 8:105-110.

85. Vovlas, N., Rapoport, H. F., Jiménez Díaz, R. M., and Castillo, P. 2005. Differences in feeding sites induced by root-knot nematodes, Meloidogyne spp., in chickpea. Phytopathology 95:368-375.

86. Zijlstra, C., Donkers-Venne, D. T. H. M., and Fargette, M. 2000. Identification of Meloidogyne incognita, $M$. javanica and $M$. arenaria using sequence characterised amplified region (SCAR)-based PCR assays. Nematology 2:847-853. 